\title{
Constitutions, Corporations, and Corruption: American States and Constitutional Change, 1842 to 1852
}

\author{
JOHN JOSEPH WALLIS
}

Between 1842 and 1852, eleven states adopted new constitutions, simultaneously creating procedures for issuing government debt and for chartering corporations through general incorporation acts. Why simultaneously? Voters wanted geographically specific infrastructure investments but opposed geographically widespread taxation. States resolved the dilemma by developing several innovative public finance schemes. One, "taxless finance," used borrowed funds and special corporate privileges without raising current taxes. Another scheme, "benefit taxation," coordinated the incidence of taxes with the geographic benefits of investments through the property tax. After the fiscal crisis of the early 1840 s, states changed their constitutions to eliminate taxless finance in the future.

B etween 1790 and 1860 the United States population moved west over the Appalachians and across the Gulf plains, creating new states as they went. The states, with some federal assistance, constructed a system of finance and transportation to tie the nation together. The states also developed a set of economic institutions that allowed free entry into the corporate form, limited the ability of governments to incur unfunded debts, encouraged generally responsible public finance, and demonstrated that a democratic republic could deliver on a commitment to secure private property rights and the rule of law. These accomplishments are celebrated parts of American economic history. Were they related? Specifically, did state government efforts to provide the physical and commercial infrastructure lead to changes in, or follow from, existing economic and political institutions?

The Journal of Economic History, Vol. 65, No. 1 (March 2005). (C) The Economic History Association. All rights reserved. ISSN 0022-0507.

John Joseph Wallis is Professor, Department of Economics, University of Maryland, College Park, MD 20742, and Research Associate National Bureau of Economic Research, E-mail: wallis@econ.umd.edu.

This article was first presented at the NBER Development of the American Economy Summer Institute. Naomi Lamoreaux and Lee Alston gave several important suggestions at the very beginning and good advice thereafter, as did Andy Rutten, Chris Hanes, Howard Bodenhorn, Gavin Wright, William Novak, Richard Johns, Robert Wright, Alan Olmstead, Lee Craig, Yoram Barzel, Michael Holt, and Doug North. Jeremy Atack and two anonymous referees were very helpful. The article benefited from comments and suggestions from participants at seminars at the University of Illinois, Northwestern University, Washington University, the University of Washington, the University of Virginia, the University of California at Davis, the University of Mississippi, Stanford University, University of Pennsylvania, Lehigh University, Duke University, the Public Choice Society meetings; and support from NSF Grant \#0241699. Discussion with Barry Weingast improved every part of the article. 
The development of two specific economic institutions that developed first in the United States - transparent corporate forms with secure stockholder rights and hard budget constraints for governmentsfollowed the collapse of state efforts to promote banks, canals, and railroads. ${ }^{1}$ In 1842 , eight states and the Territory of Florida were in default on their debts and three other states were in perilous financial condition. The simultaneous adoption of new methods for chartering corporations and regulating the issue of government debt offers a unique opportunity to explain why American economic and political institutions changed so rapidly and dramatically. Between 1842 and 1852, 11 states wrote new constitutions. Ten of these contained provisions that legislatures adopt new procedures for authorizing government borrowing and eight of the ten states required state legislatures to pass general incorporation laws. No existing economic history links the two reforms, yet there was a strong relationship underlying their simultaneous adoption. The importance of corporations and debt issue for the public finance of state governments, working through the alternative ways of financing canals and banks used by states in the 1820s and 1830s, is the link connecting the two reforms. When state finances collapsed, states looked to their own histories of borrowing and spending to understand how they got into their predicaments.

The uniform adoption of democratic and republican institutions of government and the widespread adoption of near universal white male suffrage by the 1820 s created political pressure on state governments to promote economic growth through investments in banks and canals. These pressures were particularly strong wherever large amounts of undeveloped land stood to appreciate in value from better transportation and financial infrastructure. But democracy posed another problem for the building of canals and banks: geographic competition. When, for example, New York contemplated the Erie canal, the primary opposition came from farmers along the Hudson and on Long Island who gained nothing from a canal benefiting upstate land owners. Because tax liabilities for the canal were spread throughout the state, most counties expected to be worse off if the canal were built: they gained nothing and paid higher taxes.

\footnotetext{
${ }^{1}$ The specific institutions of transparent and secure corporate forms and hard budget constraints for governments are the subject of an active and growing literature in the empirical study of economic growth. The general importance of institutions is the subject of Rodrik, Subramanian, and Trebbi, "Institutions"; Acemoglu, Johnson, and Robinson, "Colonial Origins" and "Reversal." On connections between legal systems, financial development, and economic growth see Beck and Levine, "Legal Institutions." For the importance of hard budget constraints Qian and Weingast, "Federalism"; Inman, "Transfers"; and Rodden and Eskeland, Fiscal Decentralization.
} 
This scenario played out again and again as states struggled to provide geographically specific services funded by general taxation, and their solutions shared common characteristics. It was impossible to spread the benefits equally, as no state could build a canal to every county. But it was possible to develop creative ways of financing projects. One of the methods, "benefit taxation," tied taxes paid by land owners to the benefits they received from projects using ad valorem property taxation. Other schemes involved a variety of ways to finance the construction of projects without raising current taxes; what can be termed "taxless finance." Taxless finance usually involved tax payers assuming a contingent liability. As long as the bank or canal under consideration was a financial success, the tax payers bore no costs. The economic depression that began in 1839 , however, doomed the financial hopes of the states and realization of the contingent liabilities triggered the state financial crisis of the 1840s. Constitutional changes after 1842 were specifically designed to eliminate taxless finance. As long as corporate chartering played a significant role in state finances, charter policy was closely tied to taxless-finance proposals. The lesson that state governments thought they learned in the 1840s was that taxes must be raised when spending is contemplated. If taxes are not raised, taxpayers and politicians may not adequately factor in the risks of higher taxes in the future. This is equally a lesson for developing and developed countries at the beginning of the twenty-first century.

\section{CONSTITUTIONAL CONCEPTS AND HISTORICAL BACKGROUND}

When the United States of America declared its independence, all 14 governments - one national and 13 state-assumed sovereign powers. In 1790 neither the new national constitution nor the 13 state constitutions said anything about the creation of corporations, limitations on the amount of government debt, or how to borrow, and placed few limits on taxation. $^{2}$ In the 1840 s states adopted general incorporation acts, procedural debt restrictions, and uniform property taxation, each of which is discussed in turn.

\section{General Incorporation}

In the United States, the federal and state governments both assumed the power to create corporations. Initially, all corporations were "spe-

\footnotetext{
${ }^{2}$ For the history of early state constitutions see Adams, First American Constitutions; Kruman, Between Authority; and Tarr, Understanding State Constitutions.
} 
cial": created by an act of the legislature that specified the rights and responsibilities of each corporation individually. Americans immediately began making wider use of the corporate form than the British. States chartered banks in significant numbers in the 1790s and by the $1810 \mathrm{~s}$ were incorporating business firms of all types. ${ }^{3}$ Americans consciously developed new forms of business association. ${ }^{4}$ State legislatures intensely debated the creation of new corporations. On the one hand, Americans innately distrusted corporations and their grants of special privilege. The numerous examples of truly special privileges created by state legislatures gave substance to concerns about corruption. For example, the Camden and Amboy railroad obtained a monopoly of the northeast to southwest rail route in New Jersey, connecting New York and Philadelphia, in return for giving a substantial block of stock to the state. In New York, the Albany Regency headed by Martin Van Buren, granted bank charters only to its political allies. In Arkansas, the state chartered a bank and capitalized it by issuing state bonds, and then allowed the bank to be controlled by two powerful families. ${ }^{5}$

On the other hand, two powerful positive forces counterbalanced concerns about corporations. One force was personal interest. Americans tended to distrust corporations in general, but to favor those that served their specific interests. ${ }^{6}$ The other force was aversion to taxation: corporations often contributed handsomely to the state Treasury. New York, Pennsylvania, Maryland, and Massachusetts all invested in or owned stock in banks by 1810 . The Massachusetts tax on bank capital accounted for over 50 percent of state revenues by the 1830 s. In Pennsylvania, bank charter fees and dividends on state-owned bank stock accounted for over 30 percent of state revenues between 1800 and 1830 .

\footnotetext{
${ }^{3}$ In the decade of the 1800s New York averaged 18 incorporations per year, Ohio 1, Maryland 2, Pennsylvania 6, and New Jersey 4. In the 1830s New York averaged 57, Ohio 43, Maryland 18, Pennsylvania 38, and New Jersey 18. Evans, Business Incorporations. There is a substantial historical and legal literature on American corporations: Davis, Corporations; Dodd, American Business Corporations and "Statutory Developments"; and Hurst, Legitmacy. Also see Handlin and Handlin, Commonwealth; Seavoy, Origins; Maier, "Revolutionary Origins" and "Debate"; Lamoreaux, "Partnerships"; and Dunlavy, "From Citizens."

${ }^{4}$ See Angell and Ames, Treatise; and Hurst, Legitimacy: "In sum, when we began making important use of the corporation for business in the United States from about 1780, there was little relevant legal experience on which to draw. For 100 years, we proceeded to use the corporate instrument on a scale unmatched in England. In that development we built public policy toward the corporation almost wholly out of our own wants and concerns, shaped primarily by our own institutions." pp. 8-9.

${ }^{5}$ The Camden and Amboy is discussed in Cadman, Corporation; the chartering of banks in New York under the Albany Regency in Seavoy, Origins; and Benson Concept; and the Arkansas bank in Worley, "Control" and "Arkansas."

${ }^{6}$ Maier, "Debate," pp. 73-74.
} 
Alabama and Georgia replaced their state property taxes with dividends from state owned banks in the early 1830 s.

There were few limits on what states could do to raise revenues, and the ability to generate revenues by selling privileges was widely supported as a way to reduce taxes. The ability of states to extract revenues in return for corporate privileges depended on the value of the privileges. Grants of monopoly or exclusive franchise were more highly valued than privileges available to all. As long as legislatures granted charters individually, states faced a constant conflict over how many charters they should issue and they had to continuously balance the possibility of creating (and charging for) private rents by limiting charters against the benefits of wider public access to corporate forms and lines of business. A way to avoid conflict was a general incorporation act. General incorporation acts removed most the rents associated with corporate charters by allowing free entry. General acts created an administrative mechanism to charter corporations, and all corporations shared common features with respect to stockholders, internal structures, and liability — creating more transparent corporate forms with stronger guarantees of shareholder rights. ${ }^{8}$ Opening entry reduced the revenue that states received from selling charters, but it also eliminated the political pressure on states to create special privileges through special charters. In the $1840 \mathrm{~s}$ state constitutions began to require that legislatures pass general incorporation laws. ${ }^{9}$

\section{Procedural Debt Limitations}

The power to incur debt was another sovereign power assumed by American governments. In addition to promoting banks, states were

\footnotetext{
${ }^{7}$ In the 1820 s and 1830 s taxes on bank capital or charter fees were over 25 percent of revenues in Connecticut, Delaware, Massachusetts, Pennsylvania, and North Carolina. Wallis, Sylla, and Legler, "Interaction," p. 126. We do not have adequate fiscal data on Alabama and Georgia, but see Brantley, Banking, for Alabama and Wallenstein, From Slave South for Georgia. In a similar way, dividends and transportation taxes on the Camden and Amboy Railroad enabled New Jersey to do away with its property tax in the 1840s, Cadman, Corporation.

${ }^{8}$ The general problem of promoting enterprise through corporate chartering and the conflicts that could cause with the state's fiscal interest are discussed in Wallis, "Market Augmenting Government." For a detailed and explicit example of the problem, see Pennsylvania's considerations over how many banks to charter in Wallis, Sylla, and Legler, "Interaction"; and Schwartz "Beginning." The first general incorporation act was for manufacturing firms in New York in 1811. For a history of general incorporation law, Evans, Business Incorporations.

${ }^{9}$ The major difference between special and general incorporation was free entry. Special incorporation was defined by the an act of the state legislature creating the corporation. As will be discussed later in the article, there were many varieties of special incorporation, and by the end of the nineteenth century most states that created special corporations did so under conditions of virtual free entry.
} 
deeply involved in promoting improvements in transportation. In the 1790 s and 1800s this typically involved subsidies or stock purchases in bridge, road, and turnpike companies. Rents were problematic in transportation, as these were rarely profitable investments for state governments. ${ }^{10}$ But in 1817 New York embarked on the largest infrastructure project of its time, the Erie Canal. Completed in 1825, it soon returned funds to the state over and above maintenance costs and interest payments. Just as banks proved profitable investments and sources of tax revenues for states in the 1800 s and 1810 s, it now appeared canals could as well. In the late 1820s Ohio, Pennsylvania, and Maryland started canals, all with hopes they would pay for themselves and return a handsome dividend to the state treasury.

In the mid-1830s, spurred by the rapidly expanding economy and the boom in federal land sales, states throughout the country began, or expanded, their transportation and banking investments. In 1836 and 1837 Indiana, Illinois, Michigan, and Massachusetts started new canals and railroads, while New York, Ohio, and Pennsylvania committed to expanding their systems. Banks dominated southern investments. Louisiana invested \$23 million in banks beginning in 1824. Alabama, Georgia, and Florida made substantial investments in the early 1830s, and Mississippi and Arkansas committed millions to banks in 1837 and 1838. State debts expanded from a few million in 1820 , to $\$ 80$ million in 1830 , and $\$ 200$ million in 1841 . The total and per capita amounts outstanding in 1841 are given in Table 1, and annual debt issued each year as well as the total debt outstanding is given in Figure $1 .{ }^{11}$ Unfortunately, the boom in canal, railroad, and bank investment came to a rapid and unhappy end in the depression that began in 1839. By the summer of 1842 , eight states and the Territory of Florida were in default on interest payments. Table 1 also notes whether a state defaulted. Ultimately, Mississippi and Florida repudiated their debts outright, and Louisiana, Arkansas, and Michigan repudiated part of their debts. New York, Ohio, and Alabama barely avoided default. ${ }^{12}$

\footnotetext{
${ }^{10}$ The classic history of government involvement in transportation remains Goodrich, Government Promotion, which has been supplemented by Larson, Internal Improvements. New York, Pennsylvania, and Maryland all chartered private companies to build western transportation routes. All of the private companies failed.

${ }^{11}$ The relative size of these investments is truly amazing. In 1836 Indiana, with a population of roughly 600,000 and a state budget of $\$ 50,000$ a year, authorized a bond issue of $\$ 10,000,000$ in 5-percent bonds. Michigan, with a population of no more than 200,000 and state revenues of $\$ 17,000$ in 1836 , authorized a bond issue of $\$ 5,000,000$ of 5-percent bonds in 1837 .

${ }^{12}$ For the history of state defaults see McGrane, Foreign Bondholders; Ratchford, American State Debts; and Wallis, Sylla, and Grinath, "Sovereign Debt."
} 
TABLE 1

TOTAL STATE DEBT AND DEBT PER CAPITA IN 1841, WHETHER A STATE DEFAULTED OR RESTRICTED DEBT, AND TOTAL STATE DEBT 1880

\begin{tabular}{|c|c|c|c|c|c|}
\hline State & $\begin{array}{c}\text { Total State Debt } \\
1841\end{array}$ & $\begin{array}{c}\text { Debt Per } \\
\text { Capita } \\
1841\end{array}$ & $\begin{array}{l}\text { Did the State } \\
\text { Default? }\end{array}$ & $\begin{array}{l}\text { Did the State } \\
\text { Adopt Debt } \\
\text { Procedures? }\end{array}$ & $\begin{array}{c}\text { Total State Debt } \\
1880\end{array}$ \\
\hline Florida & $\$ 4,000,000$ & $\$ 74.07$ & $\mathrm{Y}$ & $\mathrm{N}$ & $\$ 1,280,500$ \\
\hline Louisiana & $\$ 23,985,000$ & $\$ 68.14$ & $\mathrm{Y}$ & $\mathrm{Y}$ & $\$ 22,430,800$ \\
\hline Maryland & $\$ 15,214,761$ & $\$ 32.37$ & $\mathrm{Y}$ & $\mathrm{Y}$ & $\$ 11,277,111$ \\
\hline Illinois & $\$ 13,527,292$ & $\$ 28.42$ & $\mathrm{Y}$ & $\mathrm{Y}$ & $\$ 281,059$ \\
\hline Arkansas & $\$ 2,676,000$ & $\$ 27.31$ & $\mathrm{Y}$ & $\mathrm{N}$ & $\$ 2,813,500$ \\
\hline Michigan & $\$ 5,611,000$ & $\$ 26.47$ & $\mathrm{Y}$ & $\mathrm{Y}$ & $\$ 905,150$ \\
\hline Alabama & $\$ 15,400,000$ & $\$ 26.06$ & $\mathrm{~N}$ & $\mathrm{~N}$ & $\$ 9,008,000$ \\
\hline Pennsylvania & $\$ 33,301,013$ & $\$ 19.32$ & $\mathrm{Y}$ & $\mathrm{Y}$ & $\$ 21,561,990$ \\
\hline Mississippi & $\$ 7,000,000$ & $\$ 18.62$ & $\mathrm{Y}$ & $\mathrm{N}$ & $\$ 379,485$ \\
\hline Indiana & $\$ 12,751,000$ & $\$ 18.59$ & $\mathrm{Y}$ & $\mathrm{Y}$ & $\$ 4,998,178$ \\
\hline New York & $\$ 21,797,267$ & $\$ 8.97$ & $\mathrm{~N}$ & $\mathrm{Y}$ & $\$ 8,988,360$ \\
\hline Massachusetts & $\$ 5,424,137$ & $\$ 7.35$ & $\mathrm{~N}$ & $\mathrm{~N}$ & $\$ 33,020,464$ \\
\hline Ohio & $\$ 10,924,123$ & $\$ 7.19$ & $\mathrm{~N}$ & $\mathrm{Y}$ & $\$ 6,476,805$ \\
\hline Wisconsin & $\$ 200,000$ & $\$ 6.45$ & $\mathrm{~N}$ & $\mathrm{Y}$ & $\$ 11,000$ \\
\hline South Carolina & $\$ 3,691,234$ & $\$ 6.21$ & $\mathrm{~N}$ & $\mathrm{~N}$ & $\$ 6,639,171$ \\
\hline Tennessee & $\$ 3,398,000$ & $\$ 4.10$ & $\mathrm{~N}$ & $\mathrm{~N}$ & $\$ 20,991,700$ \\
\hline Kentucky & $\$ 3,085,500$ & $\$ 3.96$ & $\mathrm{~N}$ & $\mathrm{Y}$ & $\$ 1,858,008$ \\
\hline Maine & $\$ 1,734,861$ & $\$ 3.46$ & $\mathrm{~N}$ & $\mathrm{~N}$ & $\$ 5,848,900$ \\
\hline Virginia & $\$ 4,037,200$ & $\$ 3.23$ & $\mathrm{~N}$ & $\mathrm{~N}$ & $\$ 29,345,226$ \\
\hline Missouri & $\$ 842,261$ & $\$ 2.19$ & $\mathrm{~N}$ & $\mathrm{~N}$ & $\$ 16,259,000$ \\
\hline Georgia & $\$ 1,309,750$ & $\$ 1.90$ & $\mathrm{~N}$ & $\mathrm{~N}$ & $\$ 9,951,500$ \\
\hline New Hampshire & $\$ 0$ & $\$ 0.00$ & $\mathrm{~N}$ & $\mathrm{~N}$ & $\$ 3,501,100$ \\
\hline Connecticut & $\$ 0$ & $\$ 0.00$ & $\mathrm{~N}$ & $\mathrm{~N}$ & $\$ 4,967,600$ \\
\hline Vermont & $\$ 0$ & $\$ 0.00$ & $\mathrm{~N}$ & $\mathrm{~N}$ & $\$ 4,000$ \\
\hline Rhode Island & $\$ 0$ & $\$ 0.00$ & $\mathrm{~N}$ & $\mathrm{Y}$ & $\$ 3,534,500$ \\
\hline North Carolina & $\$ 0$ & $\$ 0.00$ & $\mathrm{~N}$ & $\mathrm{~N}$ & $\$ 5,006,616$ \\
\hline New Jersey & $\$ 0$ & $\$ 0.00$ & $\mathrm{~N}$ & $\mathrm{Y}$ & $\$ 1,896,300$ \\
\hline Delaware & $\$ 0$ & $\$ 0.00$ & $\mathrm{~N}$ & $\mathrm{~N}$ & $\$ 880,750$ \\
\hline
\end{tabular}

Sources: Debt in 1841 is taken from "Report of William Cost Johnson," 1843, 27th Congress, 3rd Session, Report \#296. Debt in 1880 is taken from the 1880 Census, Valuation, Taxation and Public Indebtedness.

In the 1840s state constitutions created explicit procedures for authorizing government borrowing. State and local governments were required to identify the purpose of the debt issue; raise current taxes by an amount sufficient to service the debt; and hold a public referendum to authorize the tax increase. Procedural limitations did not cap the amount of debt a state could issue. They required state and local governments to raise taxes before they borrowed and made those taxes irrevocable until the debt had been repaid. 


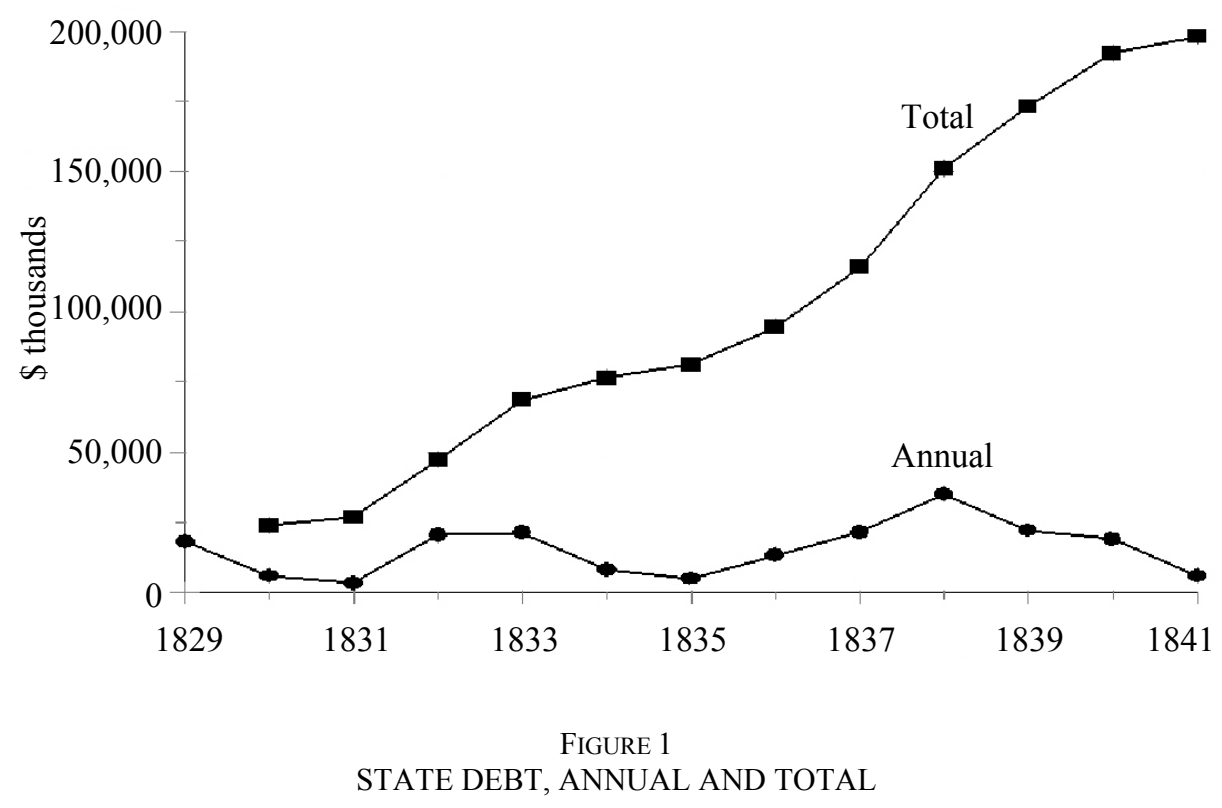

Source: Aggregate State Debt is from "Report of William Cost Johnson," 1843, 27th Congress, 3rd Session, Report no. 296.

\section{Uniform Taxation}

Finally, there were few limits on the power to tax in 1790 . The federal constitution prohibited export duties and required that direct taxes be allocated by population. State constitutions were typically agnostic with regard to taxation, although a few states did ban the poll tax. Beginning in the 1830s, southern states began adopting constitutional provisions that contained uniformity clauses requiring all wealth taxes to be levied at uniform rate and assessment with respect to value. ${ }^{13}$ After 1842 , states adopted uniformity and universality clauses that produced the general property tax: a tax imposed at a uniform rate on all wealth within the state. Most property taxes today are no longer general, as they apply only to real property wealth.

Between 1842 and 1852, 11 states replaced their existing constitutions as shown in Table 2 (Louisiana replaced its constitution twice). In all but Virginia, the new constitutions placed procedural restrictions on

\footnotetext{
${ }^{13}$ See Einhorn, "Species," for a detailed discussion of constitutional changes in tax rules. Many states, of course, essentially had uniform taxation in practice long before they put it into their constitutions.
} 
TABLE 2

STATES THAT WROTE NEW CONSTITUTIONS OR AMENDED CONSTITUTIONS BETWEEN 1842 AND 1852, AND WHETHER THE CHANGES AFFECTED DEBT, CORPORATIONS, AND TAXATION

\begin{tabular}{|c|c|c|c|c|}
\hline & Year & Debt & Corporations & Taxation \\
\hline \multicolumn{5}{|c|}{ Wrote New Constitutions } \\
\hline Rhode Island & 1842 & $\mathrm{Y}$ & $\mathrm{Y}$ & $\mathrm{Y}$ \\
\hline New Jersey & 1844 & Y & Y & Y \\
\hline \multirow[t]{2}{*}{ Louisiana } & 1845 & $\mathrm{Y}$ & $\mathrm{Y}$ & $\mathrm{Y}$ \\
\hline & 1851 & $\mathrm{Y}$ & $\mathrm{Y}$ & $\mathrm{Y}$ \\
\hline New York & 1846 & $\mathrm{Y}$ & $\mathrm{Y}$ & \\
\hline Illinois & 1848 & $\mathrm{Y}$ & $\mathrm{Y}$ & $\mathrm{Y}$ \\
\hline Kentucky & 1850 & $\mathrm{Y}$ & $\mathrm{Y}$ & \\
\hline Michigan & 1850 & $\mathrm{Y}$ & $\mathrm{Y}$ & $\mathrm{Y}$ \\
\hline Virginia & 1850 & & & $\mathrm{Y}$ \\
\hline Indiana & 1851 & $\mathrm{Y}$ & $\mathrm{Y}$ & $\mathrm{Y}$ \\
\hline Maryland & 1851 & $\mathrm{Y}$ & $\mathrm{Y}$ & $\mathrm{Y}$ \\
\hline Ohio & 1851 & $\mathrm{Y}$ & $\mathrm{Y}$ & $\mathrm{Y}$ \\
\hline \multicolumn{5}{|c|}{ Wrote First Constitution } \\
\hline \multirow[t]{2}{*}{ Iowa } & 1847 & $\mathrm{Y}$ & $\mathrm{Y}$ & \\
\hline & 1857 & $\mathrm{Y}$ & $\mathrm{Y}$ & \\
\hline California & 1849 & $\mathrm{Y}$ & Y & $\mathrm{Y}$ \\
\hline Wisconsin & 1848 & $\mathrm{Y}$ & $\mathrm{Y}$ & $\mathrm{Y}$ \\
\hline Florida & 1838 & & $\mathrm{Y}$ & $\mathrm{Y}$ \\
\hline \multicolumn{5}{|c|}{ Amended Constitutions } \\
\hline Arkansas & 1846 & & & \\
\hline Pennsylvania & 1857 & $\mathrm{Y}$ & & \\
\hline Michigan & 1843 & & & \\
\hline
\end{tabular}

Notes: A "Y" means that the state adopted some provisions regarding debt, corporations, or taxation. See the appendix tables for specific features of the constitutions.

Source: See the notes to Appendix Table 1.

the way state and local governments could issue debt and required legislatures to enact general incorporation laws. Why did ten states adopt both institutions at the same time? No state adopted one and not the other. The answer lies in the nature of infrastructure investment in democratic republics.

\section{LEGISLATIVE CHOICE AND INFRASTRUCTURE INVESTMENT}

The problem facing American state governments in the early nineteenth century was how to promote economic development through large-scale public investment, such as a canal. Legislatures are geographically oriented and their electoral incentives force legislators to be concerned about the incidence of state policies on their districts. Although statewide interests matter, it is primarily the effects of policies on his district that determine whether a given legislator favors a policy. Consider an expenditure policy to provide a public good, $\pi(x)=\left(P_{1}(x)\right.$, 
$\left.P_{2}(x), \ldots, P_{n}(x)\right)$ where $n$ is the number of districts, $\pi(x)$ is a public policy, and the $P_{i}(x)$ represent the incidence of the policy on district $i{ }^{14}$ The project is financed through taxes. Let $C=\sum_{i} c_{i}(x)$ be the total costs of the project. Let $T$ be the total taxes need to finance the project and assume balanced budgets so that $T=C$. Further, district $i$ 's tax share is $t_{i}$, so that its tax share for a particular project is $t_{i} C$. District $i$ 's legislator's objective function is $P_{i}(\mathrm{x})=b_{i}(x)-t_{i} C(x) .{ }^{15}$ Legislators consult only their own objective function, ignoring the effects of the project on other districts, and hence the project's social implications. When choosing between two projects, or between building a particular project and not, each legislator supports the alternative that provides her higher net benefits

Legislatures are constrained in two ways. First, passage of individual legislation is only possible if a majority of legislators benefit from the proposed legislation. This "majority rule" constraint applies to individual pieces of legislation. Logrolling makes it possible to fund individual projects (as opposed to legislation) that benefit a minority of legislators, as long as the project is paired with enough other projects that a majority of legislators receive positive net benefits from the entire package. For simplicity, the majority rule constraint requires that all of the necessary logrolls be bundled into one bill.

The second constraint applies to all of the legislation passed by the legislature. In aggregate, every individual legislator (district, county, or state) must receive positive net benefits from the sum of all legislation passed, or people in that geographic unit will "exit." The exit constraint requires, for $j$ projects and $i$ legislative districts that

$$
\left.\sum P_{i j}(x)>0 \text { (summed over } j \text { projects, } \forall i\right)
$$

The exit constraint requires that no district is hurt, on balance, by the aggregate actions of the government.

The threat of exit may seem too dramatic for the day to day operation of a legislature, but the constraint did not bind from day to day. The constraint applies to the aggregate of all legislation and the shortest time period it applied to was a legislative session. The implicit threat of exit in early-nineteenth-century America was very real, particularly at the state level, where population movement made the exit constraint bind. ${ }^{16}$

\footnotetext{
${ }^{14}$ This approach adapts the models in Shepsle and Weingast, "Political Solutions"; and Weingast, Shepsle, and Johnsen, "Political Economy."

${ }^{15}$ Each legislator $i$ has an ideal policy of $\mathrm{x}_{\mathrm{i}}{ }^{*}$ which solves the problem $\max P_{\mathrm{i}}(x)$ and which occurs when the marginal benefits to district $i$ equals the districts costs, i.e., $b_{i}{ }^{\prime}(x)=t_{i} C^{\prime}(x)$.

${ }^{16}$ During the Revolution Vermont seceded from New York, Maine split from Massachusetts
} 
The early-nineteenth-century America population was on the move, and states adopting unpopular policies could expect to lose people to out migration. A constant factor in the national debate about public land policy was migration from the east to the west, the desire of eastern states to keep people from moving (and lowering land prices), and the hunger for population in the west (to raise land prices). In 1842 and 1843 Illinois politicians were unwilling to raise taxes to deal with their debt problem because, as then Governor Ford later wrote, "To pay immediately was out of the question. Heavy taxation then would have depopulated the country and the debt would never be paid."17

Legislatures made simultaneous decisions about the size of the project, the allocation of expenditures across districts, and the allocation of tax burdens across districts. We can characterize four general ways for states to allocate expenditures and revenues. These are fiscal solutions. The names given to the four policies stress the revenue side, but only for ease of exposition. The four policies are normal taxation, benefit taxation, taxless finance, and something for everyone. The categories are not mutually exclusive, nor are they exhaustive, but they provide a framework to discuss the choice set facing state legislatures in the early nineteenth century.

\section{Normal taxation}

Large projects have several relevant characteristics. First, they require very large expenditure relative to the budget, implying that at most only one or two such projects can be built at once. Second, these projects concentrate the benefits in a small geographic area while spreading the tax costs across the entire state. This implies that some districts receive large benefits relative to their tax cost: $b_{i}\left(x^{*}\right)>t_{i} C\left(x^{*}\right)$; but many districts receive no benefits while bearing their tax cost, because $b_{j}(x)=0$ while $t_{j} C(x)>0$.

The concentration of benefits in a few districts implies that most districts receive no benefits but bear costs. These districts naturally prefer not to build the project. The majority rule constraint implies that no project is built. The size of the project makes it impossible to find enough logrolling options to compensate districts that do not gain from the large project. Even if it is possible to find a project that benefits a majority of districts, a simple majority fails to meet the exit constraint. In short, it is

\footnotetext{
in 1820, and West Virginia left Virginia during the Civil War.

${ }^{17}$ For a detailed consideration of the role of population movements in the national debates over land policy see Feller, Public Lands. Governor Ford in his History, p. 112.
} 
difficult for government to build a large, expensive, geographically concentrated project through normal taxation.

\section{Benefit taxation}

Instead of spreading taxes throughout the state, suppose that projects can be financed by a tax scheme, benefit taxation, whereby district $i$ 's tax share is a function of the benefits it receives from the project.

Let the $B(x)=\sum_{i} b_{i}(x)$ be the project's total benefits. Define a benefit taxation scheme so that $t_{i}=b_{i} / B$. Under this tax scheme, districts that receive no benefits from the project also pay no taxes regardless of the project's total cost: $b_{i}=0$ implies that $t_{i}=0 / B=0$. Districts pay their share in taxes in proportion to the benefits they receive. As long as the project's total benefits exceed the total costs $(B>C)$, each district with positive benefits also has positive net benefits after paying their tax share. Thus, assuming that representatives who are indifferent to the project-including legislators whose districts receive no benefits but also incur no costs-vote in favor of the project, every legislator (weakly) favors the project, so it will pass. In contrast to the case where projects are financed out of general revenue, benefit taxation implies that, even in the case of a large project such as the Erie canal, most districts receive no benefits and incur no costs, and so can costlessly support the project.

Ad valorem property taxation provided states with a potential mechanism for creating a benefit tax. If the value of transportation improvements is capitalized in land values, and property taxes are used to fund construction, it may be possible for every district to, at worst, be indifferent to the large project. The use of benefit taxation to finance a single large project simultaneously satisfies the majority and exit constraints. The central problem with a single large project is the inability to balance off the losses to districts that do not benefit from the project because the state is unable to afford multiple large projects. Benefit taxation solves this problem.

\section{Taxless finance}

There are several alternatives to financing a project through taxes. Three financing schemes share a common element-building the project does not entail raising current taxes-thus taxless finance. Suppose the canal is expected to generate a stream of toll revenues, but require state assistance in the form of eminent domain, limited liability, or some other privilege. Private entrepreneurs may be willing to privately fi- 
nance the project in exchange for a corporate charter. The value of the charter could be enhanced by granting the owners exclusive rights or other privileges. In return for the grant of special privilege, the state acquires an ownership interest in the private company. ${ }^{18}$ Public grants of monopoly were common in eighteenth- and early-nineteenth-century Britain and the United States, as was state ownership of private company stock. ${ }^{19}$ This scheme requires only that some districts benefit from the charter, as no additional taxes are raised.

The first variant of taxless finance requires that private owners raise capital themselves. In antebellum America it was difficult to use this mechanism alone to finance large transportation projects. ${ }^{20} \mathrm{~A}$ second variant of taxless finance used the good faith and credit of the state to secure operating capital by issuing bonds. The state then invested the borrowed funds in the private corporation by purchasing stock. Expected dividends from the state's investment would cover the state's interests costs. Taxpayer's liability in this case was contingent on the success of the project. If it succeeded, the state received a steady flow of dividends, net of interest costs, and taxpayers paid lower taxes. If it failed, the state and its taxpayers would assume the debt service. This variant was commonly used to finance bank investments.

Sometimes projects were so large that private entrepreneurs could not be found. A third variant of taxless finance was for a state to construct and operate the enterprise itself. The state borrowed sufficient funds to cover both building the project and the interest charges in the early years of the project before revenues were expected to materialize. Of course, borrowing funds left taxpayers with a contingent liability: if ex post the project failed to generate sufficient revenues to cover the costs of the bonds, taxpayers had to pay the difference in proportion to their tax share. The variant was commonly used to finance canals and railroads.

Taxless finance works politically because of the implicit benefit received by all districts. Current taxes may not rise, but taxpayers assume a contingent liability

$$
C L_{i}=t_{i} C(x)(1-s)
$$

\footnotetext{
${ }^{18}$ It was common in early charters for the state to "reserve" shares of stock for the state at no cost to the state.

${ }^{19}$ The practice of granting charters to private corporations to promote public interests goes back to the very founding of British colonies in the United States and the creation of the Virginia Company in 1606.

${ }^{20}$ The inability of purely private corporations to engage in large-scale transportation projects is a central element in Callender's "Early Transportation and Banking Enterprises" argument about the need for state intervention in capital markets.
} 
where $s$ is the ex ante probability of project success. If the project fails ex post, $C L_{i}$ will be positive for all districts. If a proposed improvement only generates benefits to some districts through improvements in lower transportation costs or better financial services, then $P_{i}(x)$ is negative for a the majority of districts who receive no benefits. A taxless finance scheme that does not provide benefits to all districts, ex ante, will have a negative expected value to a majority of districts and will not be supported.

$$
P_{i}(x)=b_{i}(x)-t_{i} C(x)(1-s)<0\left(\forall i \text { where } b_{i}(x)=0\right)
$$

Taxless finance does not work that way, however. All three variants propose that the project will return money to the state treasury, either in the form of dividends on the state's investment in the private corporation or in the form of toll revenues or profits. If $M$ represents the potential profit of the enterprise to the state, then the calculation of net benefits for each district becomes

$$
P_{i}(x)=b_{i}(x)+t_{i} M(s)-t_{i} C(x)(1-s)
$$

That is, each district can expect its taxes to go down by $t_{i} M$ if the project is successful. The critical issue for districts that do not benefit directly from the canal, districts where $b_{i}(x)=0$, is whether $t_{i} M(s)><$ $t_{i} C(x)(1-s)$. Taxless finance works if it promises every district that its taxes will be lower if the project succeeds. As with benefit taxation, taxless finance can simultaneously satisfy the majority constraint and the exit constraint.

\section{Many Projects: Something for Everyone}

The emphasis on single large projects is relevant for state investments in the $1830 \mathrm{~s}$. But it was also possible to promote transportation and financial investments through small projects. The legislature might choose a policy of universalism, or something for everyone: build a project in each district. ${ }^{21}$ The intuition is simple. Suppose that spending is allocated among districts by some formula or rule of thumb (such as

\footnotetext{
${ }^{21}$ Various "universalism theorems" show that, in comparison to the uncertainty of partisan politics (e.g., minimum winning coalitions) that build fewer projects than one for each district (but at least a majority), every legislator is better off under universalism (Niou and Ordeshook "Universalism"; Shepsle and Weingast, "Political Solutions"; and Weingast "Rational Choice Perspective").
} 
equal grants per capita). The grant share to individual districts are given by $g_{i}$

$$
P_{i}(x)=b_{i}\left(g_{i} x\right)-t_{i} C(x)
$$

Further suppose that at an arbitrarily small amount of spending, $\varepsilon$, produces net benefits for all districts

$$
P_{i}(\varepsilon)=b_{i}\left(g_{i} \varepsilon\right)-t_{i} C(\varepsilon)>0 \forall i
$$

Now the only problem facing the legislature is how much to spend. If the exit constraint is binding, expenditures will increase until the first district receives no net benefits. If the exit constraint can be eased by logrolling, then expenditures can increase further.

A simple virtue of something for everyone policies is that the same formula can often be used to allocate taxation and expenditures. For example, states that rely on poll taxes for some share of the revenue could allocate expenditures by the share of poll taxes paid in the state. Or poll taxes could be raised to finance education and education funds could be divided by counties according to share of the state's school-age children living in each county. The $t_{i}$ and $g_{i}$ need not be the same. They only need to be known.

States can finance investments in transportation and finance in any of these four ways. Building a canal or bank with limited geographic benefits, however, was politically infeasible using normal taxation. Too many geographic interests obtained nothing except the prospect of higher taxes. Building financial and transportation infrastructure with something for everyone policies was politically feasible, but fiscally impossible. Something for everyone policies required equal, or close to equal, allocation of funds to every district. A large canal or bank investment could be made with benefit taxation or taxless finance. Benefit taxation worked very differently from taxless finance, however. Benefit taxation required that taxes be raised simultaneously with the onset of construction and borrowing. Taxless finance allowed taxpayers to assume a contingent tax liability, one that would only be assumed in the event the project failed. Both benefit taxation and taxless finance held out the promise of significant benefits. ${ }^{22}$ We turn next to the policies used by states to finance investment in the $1830 \mathrm{~s}$.

\footnotetext{
${ }^{22}$ Benefit taxation and taxless finance were not mutually exclusive policies, a state could use a little of each. Both benefit taxation and taxless finance legislation were easier to pass when there were large expected returns from the project.
} 


\section{STATE EXPERIENCE WITH BANK AND INTERNAL-IMPROVEMENT INVESTMENTS}

States made substantial investments in early-nineteenth-century banking and transportation. By 1836 the states had chartered over 600 banks, with an authorized capital of $\$ 480$ million and paid in capital of almost $\$ 250$ million. State investment was at least $\$ 80$ million. ${ }^{23}$ Between 1790 and 1860 state and local governments spent over $\$ 425$ million on transportation investments, whereas the federal government spent only $\$ 54$ million. State governments, by any measure, played a central role in the promotion of financial and transportation investment and development. $^{24}$

By 1830 states were able to draw on 40 years of experience with bank investments. They had reasonable expectations that " $M$ " was large and positive, and that the probability of a successful investment, "s," was close to one. Canal investments in New York and Ohio were profitable. Governor Ford spoke directly to the ex ante expectations of Illinois politicians in 1837 when he explained how the state got itself into difficulties: "No scheme was so extravagant as not to appear plausible to some. The most wild expectations were made of the advantages of a system of internal improvements, of the resources of the State to meet all expenditures, and of our final ability to pay all indebtedness without taxation. Mere possibilities appeared to be highly probable, and probabilities wore the livery of certainty itself." 25

In 1841 states owed $\$ 198$ million on outstanding bonds issued to finance investments in canals, railroads, and banks. In addition, by 1841 New York and Ohio had redeemed $\$ 13$ million in bonds issued in the 1820 s to build early canals. Table 3 breaks down the $\$ 211$ million in

\footnotetext{
${ }^{23}$ There is no estimate of how much state governments invested in banks. States had borrowed $\$ 66$ million to invest in banks by 1841 (see Wallis, Sylla, and Grinath, "Sovereign Debt"). States such as New York, Pennsylvania, Maryland, and Virginia had extensive bank holdings not purchased or acquired with borrowed funds. Those were given a ball park figure of $\$ 14$ million to produce the $\$ 80$ million figure in the text, a figure that is certainly too low. The history of early-nineteenth-century state banks can be found in Bodenhorn, History and State Banking.

${ }^{24}$ Figures on state and local transportation expenditure are taken from Goodrich, Government Promotion; and on federal expenditures from Malone, Opening the West. The idea that government in the early nineteenth century was "laissez faire" was based solely on the experience of the federal government. The venerable set of studies on early-nineteenth-century state government policies sponsored by the Committee on Research in Economic History showed indisputably that state government actively promoted economic development policies. This "commonwealth" literature includes Handlin and Handlin, Commonwealth; Hartz, Economic Policy; Benson, Concept; Goodrich, "Revulsion" and Government Promotion; and Heath, Constructive Liberalism.

${ }^{25}$ Quoted in House Document, 29th Congress, First Session, \#226, p. 1051, from the Governor's Message of 8 December 1842.
} 
TABLE 3

STATE INVESTMENT IN INTERNAL IMPROVEMENTS BY METHOD OF FINANCE, FOR DEBT ISSUED BEFORE 1841

\begin{tabular}{llll}
\hline \hline \multicolumn{1}{c}{ Method } & $\begin{array}{c}\text { Predicted } \\
\text { Financing }\end{array}$ & $\begin{array}{c}\text { Amount } \\
\text { Financed }(\$)\end{array}$ & \\
\hline Normal taxation & None & 0 & \\
Something for Everyone & None & 0 & \\
Benefit Taxation & Positive & 53 million & \\
Taxless Finance & Positive & 53 million & Southern banks \\
& & 80 million & Northern transportation \\
Total & & 186 million & \\
& & &
\end{tabular}

Notes: The table gives the predictions of the model for each type of finance, and the total amount of debt financed spending on finance and transportation projects undertaken by states up to 1841 . The total is $\$ 186$ million out of $\$ 211$ million in debt issued, which includes $\$ 198$ million in state debt outstanding in 1841 and \$13 million in New York and Ohio debt issued in the 1820 s and 1830 s and retired before 1841 .

Source: Debts were taken from "Report of William Cost Johnson," 1843, 27th Congress, 3rd Session, Report \#296.

debt by the method used to finance state projects. None of the states documented in the table issued debt and expected it to be paid back through normal taxation, and no state expenditures were allocated within states on the basis of something for everyone type formulas. ${ }^{26}$

Several states implemented benefit taxation. Opposition to the Erie canal came from farmers on the Hudson and Long Island who faced competition from new lands in western New York, and from New York City commercial interests who feared higher state taxation. New York did not expect the Erie Canal to be as successful as it was, and the bill authorizing the canal set aside three additional sources of revenue for the canal fund. These were a share of the auction duties collected in New York City, revenues from the salt tax levied on the production of salt in (primarily) western New York, and a special property tax surcharge. The surcharge was to be levied on lands within 25 miles of the canal (the initial bill only authorized construction on the middle section of the route) was intended to capture the benefits of canal construction accruing to those geographic areas closest to the canal. The "canal tax" provision was they key element in the compromise between canal supporters and opponents. ${ }^{27}$ As it happened, the canal tax was never levied, because the Erie returned unexpected revenues to the canal fund and eventually to the general fund of the state. In fact, New York was able

\footnotetext{
${ }^{26}$ Education and road subsidies were regularly allocated on the basis of population or enrolled students, but no debts were incurred for these purposes.

${ }^{27}$ This paragraph is taken largely from Miller, Enterprise, chapter 4 in particular. The canal property tax is discussed on pages 69 to 73 .
} 
to suspend its state property tax entirely in the 1820 s as a result of revenues earned from the canal.

Similar taxing arrangements were established in Ohio, Indiana, and Illinois. As in New York, the chief opposition to canals was geographic; opposition came from those areas through which the proposed canals would not pass. In each of these states prior to the authorization of canal construction, land was classified into quality grades and taxed on a per acre basis equally within each classification. In Ohio in 1828, in Indiana in 1836, and Illinois in 1837 and 1839, the key compromise between canal opponents and supporters was the adoption of ad valorem taxation. In each state the passage of a canal bill was tied to the restructuring of state property taxation in order to shift more of the burden of financing canal debt onto those counties whose land values would, presumably, rise with the construction of the canals. ${ }^{28}$ Expenditures made under these arrangements in New York, Ohio, Indiana, and Illinois came to $\$ 53$ million dollars between 1817 and 1841 (Table 3). ${ }^{29}$

Taxless finance required little or no immediate financial commitment from the states. Southern states lent support to banks by purchasing bank stock or by making outright loans to banks. ${ }^{30}$ For example, Mississippi chartered a number of banks in the 1830s (prior to that Mississippi had only one bank in which the state had a financial interest). The state assisted two of the largest banks, subscribing to $\$ 2$ million in stock of the Planter's Bank in 1830, and loaning \$5 million in state bonds to the Union Bank in 1838. The charters for both banks stipulated the banks would service the bonds. ${ }^{31}$ Although the state was ultimately liable for its debts, Mississippi anticipated the banks would pay dividends to the state, that other taxes would be lower, and that the state would never pay a penny to service its bonds. The state had, after all, been receiving dividends on its bank holdings since the early 1820s. Similar arrangements were made with banks in Florida, Alabama, Louisiana, and Ar-

\footnotetext{
${ }^{28}$ Scheiber, Ohio Canal Era, describes the process in Ohio. Wallis, "Property Tax," describes Indiana. The situation in Illinois is a bit murky. Although the Illinois constitution required that all property be taxed by value, Illinois finessed the constitutional requirement by declaring that all land fell in one of three value classification. In February 1839, the state began taxing on assessed value, Haig, History, p. 79.

${ }^{29}$ This is based on the following debts in 1841: Indiana \$13 million, Illinois \$12 million, Ohio $\$ 15$ million, as well as the $\$ 7$ million issued for New York to build the Erie and the $\$ 6$ million issued by Ohio in the 1820 s to build its first canals. This does not include the $\$ 22$ million in New York debt in 1841 incurred after the state abandoned the state property tax.

${ }^{30}$ For southern banks in general see Schweikart, Banking; for southern property banks in particular see Sparks, History.

${ }^{31}$ Section 7 of the Mississippi charter of the Union Bank required that "Both the capital and interest of the said bonds shall be paid by said bank, at the times they shall severaly [sic] fall due." Laws of Mississippi, Adjourned Session, 1837, 21 January 1837.
} 
kansas. State investments in banks in the five states totaled \$53 million in the $1820 \mathrm{~s}$ and $1830 \mathrm{~s}$ (Table 3 ). ${ }^{32}$ Although there were serious sectional debates within states about the establishment of banks, there was no intrastate debate over the allocation of taxation. The states expected that the state bonds issued to these banks would never burden the taxpayers and that bank stocks would pay a net dividend. This contributed to the eventual repudiation of debts, in whole or part, in Florida, Mississippi, Louisiana, and Arkansas.

Taxless finance played an important role in transportation finance as well. The success of the Erie Canal and the Ohio canals led several states to anticipate that they could finance canal investments without raising taxes. This involved the costly requirement of meeting interest payments in the first years of construction out of borrowed funds, increasing the total amount of debt needed to finance the completed project, but obviated the politically costly need to raise current taxes. Canal and railroad investment in New York in the 1830s, Maryland, Pennsylvania, and Massachusetts all proceeded without a concurrent increase in state taxation. State expenditures financed in this manner in these states amounted to $\$ 80$ million between the late 1820 s and the early 1840 s (Table 3). ${ }^{33}$

This brief review of state financial practices encompasses $\$ 186$ million in state expenditure for banks, canals, and railroads out of the $\$ 211$ million of state debt issued before $1841 .{ }^{34}$ States either addressed the problem of competing geographic interests by tailoring their system of taxation to coordinate benefits and taxes or they made intrastate disputes moot by avoiding the need to raise taxes at all. Voters and legislators were easily convinced that building canals and banks without raising taxes was a good idea.

\footnotetext{
32 The \$53 million figure is composed of \$15 million for Alabama, \$4 million for Florida, \$7 million for Mississippi, \$2.6 million for Arkansas, and \$24 million for Louisiana. Some of the debt issued in support of the Alabama bank after 1837 should perhaps not be included in the total, as the state at that point was trying to prop up the bank after the Panic of 1837 . There was no immediate prospect that the bank would service the bonds, although the state clearly hoped that the bank would do so after the crisis had passed. The national government used a similar arrangement to finance its investments in the First and Second Banks of the United States.

${ }^{33}$ This includes debt issue of \$22 million in New York, \$37 million in Pennsylvania, \$15 million in Maryland, and \$6 million in Massachusetts. Even though Indiana and Illinois made changes in their property tax systems in 1836 and 1837 , they also planned to finance early debt service out of borrowed funds.

${ }^{34}$ The remaining $\$ 25$ million was for debts incurred by states that are more difficult to categorize.
} 


\section{ELIMINATING TAXLESS FINANCE}

In October of 1839 a financial panic swept the country, leading to the suspension of specie payments by banks throughout the south and west, declining prices and land values, and a general economic depression that lasted into 1843. By mid-1840, southern states that had issued bonds on behalf of banks-Florida, Alabama, Mississippi, Louisiana, and Arkansas - found themselves besieged by bond holders who wanted the states to redeem their solemn pledge to honor the bonds with their full faith and credit. In the northwestern states-Indiana, Illinois, and Michigan - construction on state canal and railroad projects came to a halt in late 1839 . With construction at a standstill, land values began falling. It was clear by mid-1840 that these states could not service their debts from property taxes. In January of 1841 Indiana and Florida defaulted, followed shortly by other states, culminating in Pennsylvania's default in 1842 .

There is no doubt about why states defaulted. As Table 1 shows, nine of the ten states with the largest per capita debts defaulted, and Alabama, Ohio, and New York narrowly avoided default. State legislatures throughout the country were asking "how did we get in to this mess?" and "how can we prevent this from happening again?" Although conditions in every state were unique, the answers given in the 1840s shared a common theme. States got into trouble because they pursued taxless finance and the way to prevent this from happening again was to take taxless finance off the table as a method of financing infrastructure investment. Eliminating taxless finance required procedural debt limitations, general incorporation laws, and general property taxation.

Prohibiting government debt altogether might have been the simplest reaction to the default crisis. Goodrich took his title, "The Revulsion Against Internal Improvements," from Henry Adams, but the point of his paper was that the wave of constitutional reforms in the 1840 s did not stop states, and certainly not local governments, from continuing to pursue internal improvements in the 1850s and after the Civil War. Debt restrictions were procedural, not absolute. States did not close off the possibility of financing internal improvement projects by benefit taxation. Instead, they eliminated taxless finance. To understand why this was, and what the states were doing, we need to examine the constitutional changes in more detail. Table 2 shows whether a state adopted a change in its constitution that regulated debt issue, corporation policy, or taxation, as well as states that wrote new constitutions or amended existing constitutions. (Appendix Tables 1, 2, and 3 provide details for debt restrictions, corporation clauses, and taxation respectively.) 
The first complete debt clause was Article 4, Section 6, Part 4 of the New Jersey Constitution of $1844:^{35}$

The legislature shall not, in any manner, create any debt or debts, liability or liabilities, of the State which shall, singly or in the aggregate with any previous debts or liabilities, at any time exceed one hundred thousand dollars, except for purposes of war, or to repel invasion, or to suppress insurrection, unless the same shall be authorized by a law for some single object or work, to be distinctly specified therein; which law shall provide the ways and means, exclusive of loans, to pay the interest of such debt or liability as it falls due, and also to pay and discharge the principal of such debt or liability within thirty five years from the time of the contracting thereof, and shall be irrepealable until such debt or liability, and the interest thereon, are fully paid and discharged; and no such law shall take effect until it shall, at a general election, have been submitted to the people, and have received the sanction of a majority of all the votes cast for and against it, at such election; and all money to be raised by the authority of such law shall be applied only to the specific object stated therein, and to the payment of the debt thereby created. This section shall not be construed to refer to any money, that has been, or may be, deposited with this State by the government of the United States.

The New Jersey restrictions were repeated, with alterations, in other states. New Jersey limited "casual" debt to $\$ 100,000{ }^{36}$ Issue of more debt than that required legislation that specified the purpose of the debt, and the "ways and means," i.e., the tax revenues, to service the debt within 35 years (such legislation was "irrepealable"). The legislation authorizing the debt issue could not take effect until it was approved by a majority of the voters in a general election. Limits on casual debt varied from a high of $\$ 1,000,000$ in New York to a low of $\$ 50,000$ in Rhode Island, but the casual debt limit was only a limit on the debt the legislature could approve without going to the voters. The key element in the procedural restrictions was the requirement that the "ways and means" shall be provided. Legislation authorizing the bond issue had to include new taxes sufficient to service the debt, and the new taxes had to be approved by the voters. In New York and Iowa, "ways and means" was replaced with "direct annual tax," i.e., a property tax. In most states the

\footnotetext{
${ }^{35}$ A procedural restriction was included in the Rhode Island constitution of 1842, but it simply required the consent of the people before the state could borrow more than $\$ 50,000$. Its essence, but not its details, are the same as in New Jersey. All references to constitutions in the article are to Thorpe, Federal and State Constitutions, as corrected by Wallis, NBER/Maryland State Constitution Project.

${ }^{36}$ The language of the New Jersey clause follows closely the language of an amendment proposed to the New York constitution in 1842. Adoption of the 1842 amendment was delayed until the New York constitutional convention in 1846. See the discussion in Gunn, Decline.
} 
property tax would be the tax used to provide revenues. Every state but Virginia adopted procedural restrictions on debt issue. ${ }^{37}$

Only Indiana absolutely prohibited the issue of new debt. ${ }^{38}$ The door was left open for any state that wanted to borrow money to do so, as long as a tax increase sufficient to service the debt was approved by the voters before the debt was created. In this way, internal improvement spending was not prohibited, but it had to be financed by benefit taxation. ${ }^{39}$

By themselves, procedural restrictions could and did limit state debt issue (as will be discussed). But procedural restrictions alone could not close the door on taxless finance. To do that required three additional restrictions on state governments. First, states had to close off indirect ways of obligating the state or becoming entangled in the affairs of corporations. Constitutions in every state but Rhode Island and Louisiana required that "nor shall the credit of the State ever be given, or loaned, in aid of any person, association, or corporation." The prohibition was usually matched with "nor shall the State hereafter become a stockholder in any corporation or association." (both clauses from Indiana, 1851, Article 11, section 12.) Only New York, New Jersey, and Kentucky failed to prohibit stock ownership. ${ }^{40}$

Second, the states had to close off the possibility that a select group would acquire special corporate privileges in exchange for payments to the state treasury (ala the Camden and Amboy railroad). Constitutional changes in the 1840 s tied the requirement that legislatures pass general incorporation acts, with a restriction, and in some cases prohibition, on special incorporation. Most (though not all) states required general incorporation and prohibited special incorporation. In some states special incorporation was explicitly prohibited: "The General Assembly shall pass no special act conferring corporate powers." (Ohio, 1851, Article 13 , section 1). In other states special incorporation was prohibited "except for municipal purposes, and in cases where in the judgment of the

\footnotetext{
${ }^{37}$ Indiana banned all debt issue, whereas Ohio and Michigan banned new debt issue for internal improvements. Issues in Virginia revolved around the apportionment of political power between the western and eastern parts of the state.

${ }^{38}$ And in Indiana, 1851, Article X, section 5, made the usual exceptions: "No law shall authorize any debt to be contracted, on behalf of the State, except in the following cases: To meet casual deficits in the revenue; to pay the interest on the State debt; to repel invasion, suppress insurrection, or, if hostilities be threatened, provide for public defense."

${ }^{39}$ In the late nineteenth and twentieth century, this led states to create "special" governments that were geographically crafted taxing districts designed to provide a single service such as schools, water, sewers, electricity, gas, transportation facilities, and other public utilities. Construction of facilities was financed through bond issues, approved by voters, financed by property tax levies and user fees. See Mitchell, "Effectiveness".

${ }^{40}$ New Jersey prohibited local governments from holding stock. New Jersey held several million dollars in the stock of the Camden and Amboy railroad, an important source of state revenue. Kentucky had substantial investments in its state bank. Details are in the Appendix tables.
} 
Legislature, the objects of the corporation cannot be attained under general laws." (Wisconsin, 1848, Article 11, section 1). In these states the prohibition on special corporations was implicit. New York initially considered a ban on special incorporation, but in the end adopted language similar to that of Wisconsin because of the need to specify special terms in charters for municipalities and, on occasion, the need to grant specific powers of eminent domain to transportation or communication companies. ${ }^{41}$ Banks were inextricably linked with corporations in the constitutions. Although some states banned banks outright, most states required that banks be incorporated under general laws approved by the voters (free banking). ${ }^{42}$

Finally, states had to close off the option of financing internal improvements through special tax arrangements. ${ }^{43}$ States required that: "Taxation shall be equal and uniform throughout the commonwealth, and all property other than slaves shall be taxed in proportion to its value, which shall be ascertained in such manner as may be prescribed by law." (Virginia, 1850, Article 4, section 23, of course, slaves were not an issue in northern states). These clauses required ad valorem taxation for all property (land and whatever wealth was also taxed), with equal tax rates for all types of property, assessed uniformly throughout the state. The New York scheme of levying a special canal tax in the canal counties would not have been constitutional under this type of "general" property tax. The new tax restrictions, in combination with the need to specify in advance what taxes would be collected for debt service, effectively required a majority of voters to gain from any proposed investment to obtain majority support.

\section{WHAT THEY SAID ABOUT CONSTITUTIONAL CHANGE}

When Americans tried to understand what had happened in state public finance that caused the crisis in the $1840 \mathrm{~s}$, concerns over corruption were prominent in the public debate. Americans inherited a strain of political thought about the proper role and structure of government now

\footnotetext{
${ }^{41}$ New York Constitution, 1846, Article 8, Section 1: “Corporations may be formed under general laws; but shall not be created by special act, except for municipal purposes, and in cases where in the judgment of the Legislature, the objects of the corporation cannot be attained under general laws. All general laws and special acts pursuant to this section, may be altered from time to time or repealed." See the discussion in Gunn, Decline, pp. 231-32.

${ }^{42}$ States also began asserting their absolute authority to govern corporations, even after they had granted corporate charters, special or general: "All general laws or special acts, enacted under the provisions of this section may be altered or repealed by the Legislature at any time after their passage." (Ohio, 1851, Article 13, section 1).

${ }^{43}$ For a more in-depth treatment of general property taxation, and the requirements for uniformity and universality see Benson, American Property Tax; and Einhorn, "Species."
} 
called "the republican synthesis." 44 American perception that British government had become corrupted was not only a fundamental cause of the American revolution, but fear of corruption, verging on paranoia, became a dominant feature of American politics in the early nineteenth century and remained a central political concern in the $1840 \mathrm{~s}^{45}$ States had to come to grips with whether their current fiscal crises were the result of corrupt individuals manipulating the system for their own benefit or whether they were the result of systematically corrupt decisions made by state governments. Did the crises result from bad institutions or from bad individuals? If it was bad institutions, then the appropriate remedy was to alter the institutions. If it was bad individuals, then the appropriate response was to vote the rascals out. ${ }^{46}$ States, in general, decided that bad institutions were the cause of the crisis. States began calling constitutional conventions after $1842 .{ }^{47}$ We first consider constitutional debates about debt policy, then about corporations.

Although internal-improvement legislation was always controversial, it often passed initially by consensus, rather than as the result of partisan majoritarian politics. This limited the ability, ex post, of blaming a party or faction for the failure of a canal or bank. ${ }^{48}$ Indiana provides an example. The Indiana legislature authorized the issue of $\$ 10,000,000$ in

\footnotetext{
${ }^{44}$ Shallope, "Toward a Republican Synthesis" and "Republicanism."

45 "In the process, the rhetoric of corruption emerged as the common grammar of politics, so overwhelming that it became difficult to discuss public questions in any other language. The age of Jefferson bequeathed to the United States an obsession with corruption that still deeply colors the way we think about politics." Murrin, "Escaping Perfidious Albion," p. 104. See Pocock, Virtue, Commerce, and History, particularly the essays "David Hume and the American Revolution: The dying thoughts of a North Briton" and "The mobility of property and the rise of eighteenth-century sociology" for a discussion of the English concept of corruption. For the importance of parties and faction as a source of corruption in the United States see Bailyn, Ideological Origins; Hoftstadter, Idea of Party, particularly his discussion of Bolingbroke on pages 16 to 23, and the essays in Matthews, Virtue, Corruption, and Self-Interest. For a discussion of corruption in the 1790 s and 1840 s see Wallis, "Concept."

${ }^{46}$ An implication of this line of thinking is that states where the fiscal crisis was linked with venal corruption should not have changed their constitutions. There is evidence to support this interpretation in Florida, Mississippi, and Arkansas, the only defaulting states that did not adopt constitutional reforms. The evidence, however, cannot be easily encompassed in this essay.

${ }^{47}$ The default crisis peaked in 1841 and 1842, but many states did not write new constitutions until 1848 or later. States with serious financial difficulty usually waited until their fiscal situation returned to something like normal before calling a convention. In Table 2, the first group of states to write new constitutions - New Jersey, Rhode Island, New York, and Louisiana-were states whose finances were not severely disordered by the crisis. Louisiana defaulted, but for procedural reasons in the chartering of several banks, not because it lacked funds. New York came closest to default, but was able to successfully raise taxes in 1842. Of the states that wrote constitutions after 1848, Illinois, Michigan, Indiana, Maryland, and Ohio were all states whose finances were under strain, or completely disordered, until later in the decade. See Wallis, Sylla, and Grinath, "Sovereign Debt."

${ }^{48}$ This is not meant to imply that political partisans did nor try to pin blame on whatever party or administration was in power when the decision to embark on projects was made.
} 
5 -percent bonds when its state budget was only $\$ 50,000$ a year. Under a binding exit constraint, we should see that substantial consensus was required before a canal bill could pass. The two main canals in Indiana, the Whitewater in the southeast corner of the state and the Wabash and Erie, which ran from the southeast corner of the state to the north and then northeast, were the poles around which the canal interests built their majority. As Indiana historian Logan Esarey points out: "As finally organized, this [canal] party controlled every county in the State but seven-Harrison, Posey, Crawford, Switzerland, Hendricks, Perry, and Spencer; and six of these were on the Ohio. The total voting strength of these [anticanal] counties was always less than ten out of a body of eighty members." ties through which a proposed canal, railroad, or turnpike would pass) possessed a clear majority of the votes in the Senate and House as early as 1833 , yet fewer than ten of 80 legislators were able to hold up a canal bill for three years. Why? The reason appears to be the exit constraint. Indiana did not proceed with its canal system until the legislature reached a rough consensus that included every region. What brought the southern counties to support the canal system was the adoption of ad valorem taxation in 1836 . That is, the adoption of benefit taxation was critical to reaching the political consensus necessary to begin construction. $^{50}$

Because Indiana had passed internal improvement legislation by consensus, it was difficult, ex post, for one geographic group to be blamed for the decision to build the canals. Calls for a constitutional convention in the mid-1840s were generally supported by the Democrats and opposed by the Whigs. A constitutional convention, supported by Whigs and Democrats, was not called until 1850 when state finances were back on a sound footing. The voters sent almost equal numbers of Democrat and Whig delegates to the convention.

The convention regarded its main task as fixing the systematic flaws in Indiana government that produced the crisis:

Sir, we have just passed a tremendous crisis. Now is the time for us to look around and reflect. If we learn no experience from the past, if we now fail, in this period of calmness, to place upon ourselves the restrictions which will in all time to come save us from similar wide spread ruin and calamity, I hold that this Convention has been called in vain.

Look, sir, to other States. State after State has called Conventions to reform their Constitutions. All around us Constitutional Conventions are in sessions, or just

\footnotetext{
${ }^{49}$ Esarey, History, p. 410.

${ }^{50}$ The details of the Indiana history are described in detail in Wallis, "Property Tax."
} 
about to be in session. If there is a single cause more than any other, which has produced this general movement, it is the desire, on the part of the people, to cut themselves off from themselves and their representatives this power of creating public debt. ${ }^{51}$

The speaker, Mr. Read, and a majority of his fellow delegates ultimately voted to prohibit borrowing in Indiana completely, the only state to do so.

Surprisingly, there was little in the way of partisan finger pointing over the origins of the crisis. Convention delegates clearly regarded the decisions made in 1836 as the result of flaws in their democratic system rather than malign individuals. Delegates from both parties rose and denounced the policies the state had followed in 1836. So much so that Judge Kilgore, who spoke against the absolute prohibition on state debt, remarked that "I appear to be the last survivor of all the members of the Legislature of 1836 who voted for that bill. I know there are many still living, they seem to have been afflicted — perhaps in judgement for their political sins - with a loss of their memories. [Laughter]." ${ }^{, 52}$ Kilgore went on to articulate not only an explanation of what happened in 1836, but how it could be prevented in the future:

If, with the light of the past to guide them, with the heavy burthens of the present to remind them of past errors, the people coolly and deliberately decide at the ballot-boxes to again borrow money, I shall aid to place no Constitutional barriers in their way to prohibit them from carrying out their will; provided, sir, that at the time they give the Legislature authority to contract a debt they provide by direct taxation for the payment of the interest, and the canceling of the principal, within twenty-five years. Right here, sir, and nowhere's else, was the great error committed by the people and their representatives in 1836. Gentlemen may confine themselves to the simple assertion that the people of that day were mad; I shall not deny it; they were mad, and very mad; but, Mr. President, had a provision been made before the public debt was created that a direct tax must be levied, high enough to pay the interest and to wipe out the whole debt in eighteen or twenty-five years, all would have been comparatively well. A provision of this kind, sir, would have brought the people to their right senses, and my word for it, before State Bonds to the amount of four millions of dollars had been sold, they would have risen and denounced the whole system as projected. ${ }^{53}$

Judge Kilgore called for benefit taxation and castigated the perils of taxless finance, and called for a direct tax, which in 1850 meant ad valorem property taxation, before any future debt could be issued. Many delegates laid the blame for the mistake of 1836 at the feet of taxless finance. Mr. Smith of Ripley county: "It was represented to the people of

\footnotetext{
${ }^{51}$ Indiana, Report [1850], p. 660.

${ }^{52}$ Kilgore Speech, Thursday, 21 November, in Indiana, Report, [1850], vol. 1, p. 676.

${ }^{53}$ Ibid, p. 676.
} 
that day [1836], by the political leaders, that they might go on with that gigantic system of internal improvements without incurring any additional tax on themselves: in fact, the proposition was made that the State could borrow money to construct these public works, and never have to pay any taxes thereon out of their own pockets - that the debt would pay itself." 54

The new Indiana constitution required the legislature to pass general incorporation laws and banned special incorporation, but these provisions were so generally accepted that no record of a substantive debate was entered in the Debates and Proceedings of the convention. The constitution banned state investment in private corporations. Mr. Morrison of Marion county spoke in support of the ban:

I shall be found constantly voting against any proposition to connect the interests of the people with the interests of the corporations; for the reason that corporations always labor and scheme for their individual benefit, which is always antagonistic to the interests of the people. The proposition is so plain that it is unnecessary to elucidate by giving examples. Gentlemen have no interests to maintain here which should prevent them from reflecting the will of their constituents upon this subject, and the question narrows itself down to the simple proposition whether the State is to become a partner or a stockholder in any public enterprise - whether taxes shall be laid upon the people to raise capital; and then be appropriated by the State for the purpose of private speculation in any concern where individual interests are always militating against the interests of the State. The individual who stands in such a connection with the State, knows that the State will stand more shaving and peculation, and he will indulge more in this way than he would if he were acting in an individual partnership concern where his partner stands ever actively watching the operations of the concern. The State has been aptly compared to a goose, and according to the saying, he was a fool who did not pluck her. And in view of what we have suffered heretofore, I think it is but the part of prudence that we should provide for the evil to come. ${ }^{55}$

Although Indiana politicians did not use the terms taxless finance and benefit taxation, they used the logic behind the concepts. Their language spoke directly to the evils and dangers of taxless finance. They did not blame the state's fiscal crisis on faction or party, but on the perception that the constitutional organization of the state was "corrupt," in the nineteenth-century sense that it allowed the state to pursue methods of financing state investments in good faith, that in retrospect turned out to be a disaster. The problems they identified were systematic and the solutions they devised were systematic as well.

\footnotetext{
${ }^{54}$ Ibid, p. 663.

${ }^{55}$ Ibid., p. 652.
} 
The passage of constitutional provisions requiring general incorporation acts can be traced most clearly in New York. New York passed its first general incorporation act, for churches, in 1784. The state adopted a general act for the incorporation of manufacturing companies in 1811, the first law providing for the general incorporation of private business enterprises. In 1827 the Revised Statutes of the states created a general regulatory statute that governed the features that corporation charters could possess, including liability rules, capital limitations, corporation officers, and by laws. The Revised Statutes limited the ability of the state to create special corporations with special features, but a general regulatory statute could not prevent the state legislature from limiting entry. The Albany Regency under Van Buren deliberately limited access to charters for banks in order to garner political support. It was a classic case of systematic corruption. ${ }^{56}$ When the Whigs gained control of the legislature after the election of 1837, they passed the most famous general incorporation act of all, the Free Banking Act, in 1838.

But it was not until 1846 that the New York constitution was modified to mandate general incorporation. The arguments for general incorporation revolved around the issue of entry, rather than the powers and privileges given to corporations. At issue was removing from the legislature discretionary power to limit entry into a particular line of business to one or a few firms. William Leggett, a New York newspaper columnist and Loco Foco supporter, wrote extensively about general incorporation:

Nothing can be more absurd than to suppose that the advocacy of these sentiments [supporting general incorporation] implies opposition to any of the great undertakings for which special legislative authority and immunities are usually sought. We are opposed only to a violation of the great democratic principle of our government; that principle which stands at the head of the Declaration of Independence; and that which most of the states have repeated, with equal explicitness, in their separate constitutions. A general partnership law, making the peculiar advantages of a corporation available to any set of men who might chose to associate, for any lawful purpose whatsoever, would wholly obviate the objections which we urge. Such a law would confer no exclusive of special privileges; such a law would be in strict accordance with the great maxim of man's political equality; such a law would embrace the whole community in its bound, leaving capital to flow in its natural channels, and enterprise to regulate its own pursuits. ${ }^{57}$

\footnotetext{
${ }^{56}$ The literature on banking and the Albany Regency is extensive. See Benson, Concept; Seavoy, Origins; and Bodenhorn, "History."

${ }^{57}$ Leggett, Democratick Editorials, p. 342. The column appeared in the Plaindealer, 3 December 1836 .
} 
Advocates of mandatory general incorporation hammered away at the political costs of special legislation. E. P. Hurlbut, a New York lawyer, wrote in 1845, that general incorporation would annihilate "the lobby, or third house, that embodiment of selfishness and gross corruption. The halls of legislation would be cleansed, and the representatives of the people would breathe a purer and freer atmosphere. All 'logrolling'... would cease. $" 58$ As Leggett emphasized, economic benefits would flow from general incorporation, but it was the political arguments that carried the day. Eight states mandated general incorporation in their new constitutions. New York enacted "more than thirty general incorporation statutes between 1846 and 1857.",59

Legislatures typically granted charters with truly special corporate privileges only when there was a "great undertaking" with a public purpose involved. ${ }^{60}$ The charter for the Camden and Amboy Railroad, the First and Second Bank of the United States, and the monopoly state banks in Indiana, Illinois, Kentucky, and Missouri all involved the creation of special corporate privileges to serve the greater public good. In this critical sense there was little to distinguish a group of promoters who came to a state legislature with a canal or railroad project funded with state bonds to be repaid with tolls and dividends, than from a group of bankers or railroad promoters who wanted a special charter in return for providing their public service. Both were offering to provide a public good without cost to the state treasury. Because neither type of project involved raising current taxes and both types involved creating privileges for a limited group within the community, citizens and politicians came to suspect that allowing legislatures to consider taxless finance proposals amounted to courting corruption.

\section{WHY STATE DEBT AND CORPORATIONS WERE CONNECTED:}

At the beginning of the twenty-first century there is no connection between how governments borrow and their policies towards incorporation. The separation is testimony to how effectively the constitutional reforms of the 1840s separated the two issues. In the early nineteenth century, state debt issue and incorporation were closely linked both by a concern over corruption and by the history of state promotion of finance

\footnotetext{
${ }^{58}$ Hurlbut, Essays on Human Rights, pp. 11-15. As quoted in Gunn, Decline, p. 231.

${ }^{59}$ Gunn, Decline, p. 232. Gunn's entire chapter on general incorporation laws, pp. 222-45, is relevant to this issue, as is Seavoy's entire book, Origins.

${ }^{60}$ Many legislative acts chartering special corporations simply duplicated existing charters or, as in New York after 1827, enacted charters that fit pre-existing charter forms. In these states and cases, the only thing special about the charter was that the state legislature had passed it.
} 
and transportation. Corruption was generally defined as the few benefiting at the expense of the many. ${ }^{61}$ Public debts and corporations were different facets of the same problem: how to prevent a democratic republic from being captured by the interests of a narrow political elite. This was a question about the nature of democracy itself, not about the character of a handful of individuals. Promoters had come to state legislatures with proposals to finance banks, canals, turnpikes, bridges, and railroads with variants of taxless finance regularly since the $1790 \mathrm{~s}$. They realized that it was extremely difficult ex ante to distinguish the ex post good proposals from the bad proposals. This involved more than public credit. Promoters were not always interested in direct state investment. Often they asked for special privileges that guaranteed them limited competition or favorable access to markets or courts. ${ }^{62}$ State governments and citizens were learning to be suspicious of all forms of taxless finance - any promises to provide valuable public services at no cost to the taxpayers.

The connection between corporation policy and state finances came naturally to early-nineteenth-century politicians. Historically, state finances and corporate charters had been connected in a direct and observable way. Corporate charters were special acts of state legislatures that often included provisions authorizing debt issue in the same piece of legislation. For example, the charter of the Bank of Louisiana, issued in 1824, chartered the bank, authorized state bond issues, and explicitly tied dividends on the state's stock in the bank to interest on the state bonds used to purchase the stock: "That if the dividends on the stock held by the state in the said bank, shall at any time be insufficient to pay the instalments of interest on the principal of said bonds, as the same may become due, that said bank shall supply such deficiency, and charge the same to the account of the state, and for the payment thereof the faith of the state is hereby pledged." ${ }^{63}$ Similar arrangements were

\footnotetext{
${ }^{61}$ Jackson ends his veto of the Bank recharter with: "If we can not at once, in justice to interests vested under improvident legislation, make our Government what it ought to be, we can at least take a stand against all new grants of monopolies and exclusive privileges, against any prostitution of our Government to the advancement of the few at the expense of the many, and in favor of compromise and gradual reform in our code of laws and system of political economy. I have now done my duty to my country." Richardson, Messages, vol 2, pp. 557-91.

${ }^{62}$ It is easy to see that a firm could be indifferent between different packages of corporate privileges or state investment or gifts. Firms were quite willing to pay for privileges if they were valuable enough.

${ }^{63}$ The charter of the Bank of Louisiana, Laws of Louisiana, 6th Legislature, 2nd Session, 10 April 1824, "An Act to incorporate the subscribers to the Bank of Louisiana," sections 7 and 8, pp. 100-02. For a similar arrangement see the Charter of the Union Bank of Mississippi, Laws of Mississippi, Adjourned session, 21 January 1837, Section 8, p. 40.
} 
reached in bank charters throughout the country. ${ }^{64}$ The charters of early New York banks typically reserved a block of stock for the state. In Massachusetts in 1812, the state chartered the Bank of Massachusetts, with a capital of $\$ 3$ million of which the state subscribed a third. ${ }^{65}$ In Pennsylvania the state regularly negotiated with existing banks over the question of whether new banks should be chartered, effectively auctioning off charters to the highest bidder. ${ }^{66}$

A close relationship existed between chartering and state finances in transportation companies as well. The Gallatin report, issued in 1808, documented the many state connections with transportation corporations. New Jersey aided a turnpike company in 1804. Pennsylvania chartered and contributed to its first turnpike company in 1806. Virginia and Maryland contributed more than $\$ 150,000$ and purchased 340 of the 701 shares of the Potomac Company. Virginia chartered and invested in the Dismal Swamp Company and the James River Company. New York chartered and invested in the Northern Inland Lock Navigation Company and the Western Inland Lock Navigation Company. Pennsylvania chartered the Schuylkill and Susquehanna canal and stood ready to pay a $\$ 300,000$ bonus on completion of the canal. ${ }^{67}$ Virginia established a Board of Public Works in 1816. The board administered a Fund for Internal Improvements, which was based on dividends on state stock in the Bank of Virginia, the Farmers Bank of Virginia, the James River Company, the Appomattox Company, the Dismal Swamp Canal Company, the Potomac Company, and the Little River Turnpike Company. The state stood ready to subscribe up to two-fifths of the paid in stock of approved internal improvement projects. ${ }^{68}$

\footnotetext{
${ }^{64}$ The following amounts were invested in southern corporations, usually debts authorized in legislation providing corporate charters: Florida, $\$ 3,000,000,1833$, Union Bank of Florida; $\$ 400,000,1835$, Southern Life Insurance and Trust Company; and $\$ 500,000,1835$, Bank of Pensacola. Arkansas, \$1,633,000, State Bank of Arkansas in 1836, 1837, and 1838; \$1,530,000, Real Estate Bank of Arkansas in 1836 and 1837. Mississippi, \$2,000,000, 1830 and 1833, Planters Bank; and \$5,000,000, 1838, Union Bank of Mississippi. Louisiana, \$2,400,000, 1824, Bank of Louisiana, \$2,000,000, 1827, Consolidated Association of Planters (the Johnson Report does not give a date for this investment, but Caldwell dates it to 1827, Banking History of Louisiana, p. 46); \$7,000,000, 1832, Union Bank of Louisiana; \$12,000,000, 1833, Citizen's Bank of Louisiana; $\$ 600,000,1837$, Nashville Railroad Company; and $\$ 1,185,000$ for various purposes in 1839. The dates and amounts taken from the "Report of William Cost Johnson," 1843, 27th Congress, 3rd Session, Report \#296. For a detailed description of these banks, occasionally with different dates or amounts, see Sparks, Agricultural Credit, pp. 98-111, and the descriptions of individual states in McGrane, Foreign Bondholders.

${ }^{65}$ The state already had substantial bank holdings, the Handlins report a total of \$1.8 million in 1812. Commonwealth, p. 120. The discussion of Massachusetts is based on pp. 113-21; and Dodd, pp. 201-18.

${ }^{66}$ See Schwartz "Beginning"; and Wallis, Sylla, and Legler "Interaction."

${ }^{67}$ Goodrich, Government Promotion, pp. 21 and 22.

${ }^{68}$ Goodrich, Government Promotion, pp. 87-96, and "Virginia System."
} 
It would have seemed odd to a knowledgeable American in 1840 to suggest that state debt policy, state finances, and corporate chartering were independent from one another. The entire history of corporate chartering in banking and finance up to 1840 was intimately connected to state investment and finance. The constitutional changes made in the 1840 s deliberately separated corporate chartering from state debt issue, and the distance between the two policies today is a measure of the success of the institutions put in place in the 1840 s.

\section{PARTY POLITICS}

Despite their central importance in the evolution of American economic institutions, there is no general history of state constitutional change in the 1840s. An alternative to the hypothesis presented here is that the new constitutions were the work of the Democratic Party. The Whigs opposed writing new constitutions in several states: "The adamant, politically costly, and ultimately unsuccessful opposition by Whig leaders to constitutional revision in Maryland, Kentucky, North Carolina, Ohio, and Indiana is one such instance were Whigs undoubtedly suffered from 'too much respectability,' where innate conservatism put them on the losing side of an issue." ${ }^{, 69}$ Carmony's history of Indiana talks about the "Democratic" constitution of 1851. But as we have seen, the constitutional provisions that we are concerned about were not the result of partisan battles between Democrats and Whigs, nor were the conventions themselves generally partisan contests.

This does not mean that partisan issues did not intrude into the conventions. In Indiana, Democrats' proposal to exclude corporation officers from holding seats in the state legislature was defeated on almost a straight party vote. Part of the reason Whigs were reluctant to hold conventions in some states was the unequal apportionment of legislative representation across districts. In several states, new constitutions adopted more equal apportionment schemes that hurt the Whigs.

Yet, in many states party issues were not important. The New York legislature took up the issue of a constitutional amendment to limit state debt in 1842. The amendment did not pass that year, but ultimately the debate led to a constitutional convention and the New York constitution of 1846. The battle over calling the constitutional was not a party issue.

\footnotetext{
${ }^{69}$ Holt, Whig Party, p. 958. Holt's excellent and exhaustive history of the Whig party is eloquent testimony to the lack of historical interest in the 1840 s constitutions. There is not one general history of state constitutions in the references, paper, or book. There are several references to student papers in Holt's seminars about state constitutional conventions in the 1840 s, evidence of his interest.
} 
The major split over the convention was within the Democratic party, not between the Democrats and the Whigs. ${ }^{70}$ In Louisiana, the state adopted a new constitution in 1845 when the state was controlled by the Whigs, and again in 1851 when the state was controlled by the Democrats. The two constitutions had similar provisions with regard to debt restrictions, general incorporations laws, and restrictions on special incorporation. These were not party issues. Everywhere the issue was concern about the growing corruption of politicians: "The growing populistic rebellion against the regular parties and the politicians who led them as corrupt, selfish wire pullers was hardly confined to Maryland. It also helped fuel movements to revise and ratify constitutions in Ohio, Indiana, and Kentucky." "Nonetheless, the constitution seemed so popular, especially its provisions reflecting the rising tide of antipolitician, antiofficeholder sentiment in Indiana and elsewhere . .."71

In his history of the Whig Party, Michael Holt divided states in the 1840s into three groups: solidly Whig states, competitive states, and solidly Democratic states. ${ }^{72}$ Only two of the eight solidly Democratic states wrote new constitutions, Illinois and Michigan. They were both states traumatized by the debt crisis. Five of the six states where Democrats and Whigs competed on equal terms adopted new constitutions or amendments: Louisiana, Pennsylvania, Indiana, New York, and Virginia. Five of the 11 solidly Whig states adopted new constitutions: Maryland, Kentucky, Ohio, New Jersey, and Rhode Island. States where political parties competed equally were more likely to adopt constitutional changes. Constitutional changes were otherwise not connected to partisan politics.

\footnotetext{
${ }^{70}$ In New York, "Partisan divisions alone, however, do not explain either the nature of the debate over state debts and development policy or its significance. For one thing, the most intense conflict occurred within the Democratic party and was partially responsible for a breach within the leadership that would endure throughout the 1840s." Gunn, Decline, pp. 168, 178-79. "It would be extremely shortsighted, therefore, to attribute passage of the Constitution of 1846 to the machinations of political parties. To do so would be to seriously misjudge the significance of the critique of the existing constitution and to trivialize the long-run implications of constitutional change for the political system." pp. 181-83.

${ }^{71}$ Holt, Whig Party, first quote p. 1094, second quote p. 663. See Holt, Political Crisis, for a discussion of party competition between the Whigs and the Democrats in the 1840s.

${ }^{72}$ The Pro-Whig states were Rhode Island, Vermont, Kentucky, North Carolina, Maryland, Massachusetts, Delaware, Connecticut, New Jersey, Tennessee, and Ohio. The competitive states were Georgia, Louisiana, Pennsylvania, Indiana, New York, and Virginia. The ProDemocrat states were Michigan, Mississippi, Missouri, Illinois, Alabama, Maine, Arkansas, and New Hampshire. Holt, Whig Party, table 20, p. 214.
} 
TABLE 4

TOTAL AND PER CAPITA DEBT 1841, IN STATES THAT DEFAULTED AND IN

STATES THAT RESTRICTED DEBT, AND CHANGE IN DEBT 1841 TO 1880

\begin{tabular}{lcc}
\hline States that: & Defaulted & Did Not Default \\
Mean Total State Debt in 1841 & $\$ 13,118,451$ & $\$ 4,258,958$ \\
standard error & $\$ 10,100,139$ & $\$ 6,886,104$ \\
Mean Per Capita Debt in 1841 & $\$ 35$ & $\$ 4$ \\
standard error & $\$ 21$ & $\$ 6$ \\
States that: & Restricted Debt & Did Not Restrict Debt \\
Mean Total State Debt in 1841 & $\$ 12,456,069$ & $\$ 3,094,590$ \\
standard error & $\$ 10,936,273$ & $\$ 3,936,357$ \\
Mean Per Capita Debt in 1841 & $\$ 18$ & $\$ 11$ \\
standard error & $\$ 19$ & $\$ 19$ \\
States that: & Restricted Debt & Did Not Restrict Debt \\
The Change in Total Debt between 1841 and 1880 & $(\$ 5,437,797)$ & $\$ 6,274,004$ \\
standard error & $\$ 6,202,488$ & $\$ 10,245,757$ \\
States that: & Defaulted & Did Not Default \\
The Change in Total Debt between 1841 and 1880 & $(\$ 5,793,143)$ & $\$ 4,593,094$ \\
standard error & $\$ 4,508,886$ & $\$ 10,844,711$
\end{tabular}

Sources: Debt in 1841 is taken from "Report of William Cost Johnson," 1843, 27th Congress, 3rd Session, Report \#296. Debt in 1880 is taken from the 1880 Census, Valuation, Taxation and Public Indebtedness.

\section{EFFECTS AND IMPLICATIONS}

If the constitutional changes were important, then they should have large and lasting effects. This section quantifies the easy-to-measure effects, and draws implications for several areas of American economic development. Table 4 shows the relationship between total debt in 1841, per capita debt in 1841 , whether a state defaulted, whether a state restricted debt, and the change in debt between 1841 and 1880. States that defaulted had, on average, $\$ 13$ million in total debt and $\$ 35$ in per capita debt in 1841, whereas states that did not default had only \$4 million in total debt and $\$ 4$ in per capita debt. ${ }^{73}$ States that enacted constitutional restrictions on procedures for issuing debt had $\$ 12$ million in total debt and $\$ 18$ in per capita debt, whereas states that did not restrict debt had only $\$ 3$ million in total debt and $\$ 11$ in per capita debt. ${ }^{74}$ Between 1841 and 1880, aggregate nominal state debt grew slightly, from \$198 million to $\$ 236$ million. In states that adopted debt restrictions, total

\footnotetext{
${ }^{73}$ Table 4 provides standard errors for descriptive purposes only. This is the universe of states, not a sample and the absolute differences between means are the real differences, not estimates.

${ }^{74}$ Florida had the largest debts per capita and it did not restrict debt (it repudiated its debts and was shut out of capital markets). New York and Ohio had large debts, did not default, but did implement restrictions. This explains the difference between total debt and per capita debt states that restricted debt and those that did not, compared to those states that defaulted and those that did not.
} 
debt fell by $\$ 5$ million per state, whereas in states that did not adopt debt restrictions total debt rose by $\$ 6$ million. In states that defaulted, total debt fell by $\$ 6$ million per state, whereas in states that did not default rose by $\$ 5$ million per state. Both constitutional restrictions and default experience mattered, and procedural debt restrictions had a significant effect on the subsequent fiscal behavior of state governments. ${ }^{75}$

The effect of debt restrictions and the general property tax had a profound effect on the structure of state and local governments. In 1840, local government debt was one-eighth of state government debt; in 1902, local government debt was eight times state government debt. In 1840 , state government revenues were 75 percent of local government revenues; in 1902 state government revenues were 20 percent of local government revenues. ${ }^{76}$ The requirement that governments use benefit taxation (or something approaching it) shifted borrowing and spending to smaller, more homogeneous geographic units. Cities, counties, and special districts took the lead in providing basic social infrastructure investments in public utilities (water, sewage, gas, and electric), public health, and education. In aggregate these investments were enormous, but their scale was well suited for local governments. As Werner Troesken shows, America was successful at providing critical urban infrastructure in the late nineteenth century, and an important element in how well it did that was the relationship between state and local governments. Constitutional changes played a role in the decentralization of nineteenth-century American government, but how much of the change is due to changing constitutional provisions still remains to be determined. $^{77}$

Despite a few landmark Supreme Court decisions, corporate law in the United States continues to be a state, not a national, matter. In the 1840 s, states deliberately altered the way they chartered corporations to encourage entry and to limit flexibility in corporate form. General incorporation acts were intended to limit all corporations to the same rights and governance structures. Special corporations and flexible charter privileges were a source of corruption. Although strict corporate

\footnotetext{
${ }^{75}$ A simple regressions of the change in total debt between 1841 and 1880 on whether a state restricted debt shows that states that restricted debt reduced their debt by about $\$ 11$ million in contrast to states that did not restrict. In a regression where whether a state defaulted is also include, the difference between restricting and nonrestricting states falls to $\$ 9.5$ million, and the difference between states that defaulted and those that did not reduces state debt by $\$ 7$ million.

${ }^{76}$ In 1840 state debts were \$198 million and local debts were about \$25 million. In 1902 state debts were $\$ 237$ million and local debts were $\$ 1,877$ million. State revenues were $\$ .88$ per capita in 1840 and local revenues were $\$ 1.23$. In 1902, state revenues per capita were $\$ 2.44$ and local revenues per capita were \$11.44. Wallis, "American Government Finance."

${ }^{77}$ See Wallis, "American Government Finance" and "History" for elaboration of these themes.
} 
forms limited flexibility, it increased transparency, and it certainly encouraged entry. We cannot compare numbers of corporations in the 1830 s to the $1880 \mathrm{~s}$, because there are no counts of corporations, reliable or otherwise, until the IRS began collecting statistics in 1916. In 1920 there were 314,000 corporations operating within the United States. Between 1807 and 1867, however, France chartered 642 corporations. By comparison, in New England alone, 6,700 corporations were chartered between 1800 and $1862 .{ }^{78}$ We know that the adoption of a free banking law, a general incorporation law for banks, usually resulted in a substantial increase in the number of banks. So, for example, when New York adopted its free banking law in 1838, 93 free banks were created in a state with only 95 banks on 1 January 1837. Similar increases occurred in Michigan, Indiana, and Ohio. ${ }^{79}$

In her study of special incorporation, Susan Hamill finds that "From 1875 through 1996, the states issued 19,998 total special charters." 80 This suggests a very small share of corporate charters were issued to special corporations in the late nineteenth and twentieth centuries (in 1996, 4,474,167 corporations filed tax returns). But in absolute terms 19,998 is not a small number. If general incorporation acts were intended to limit special incorporation, why were so many special charters given after 1875? The answer lies in the definition of a special charter. Any charter that is issued by a legislature is a special charter, no matter what its content. Some states were reluctant to ban special charters completely because they realized the necessity of including specific and unique conditions into the charters of municipalities and other local governments, as well as in cases where eminent domain was involved. Of Hamill's 19,998 special charters, 10,685 were issued to public corporations. ${ }^{81}$ Transportation and communication companies account for another 3,933 charters. These charters typically involved questions of eminent domain, and so had to be taken on a case-by-case basis. Banking and financial institutions make up another 3,030 charters, and these charters were typically special charters because of general incorporation

\footnotetext{
${ }^{78}$ Lamoreaux and Rosenthal, "Legal Regime," pp. 5, 6, and 10, citing Freedeman, JointStock, for France and Kessler, "Incorporation" for New England. Several New England states had de facto general incorporation before they officially created laws. In fact, although many New England state passed general incorporation acts, they did not amend their constitutions to require general acts.

${ }^{79}$ The 95 bank number is taken from House Document \#111, 26nd Congress, Second Session, and the 93 free banks created is taken from House Document \#226, 29th Congress, First Session. Also see Rockoff, "Free Banking Era."

${ }^{80}$ Hamill, "From Special Privilege," n. 192, p. 129.

${ }^{81}$ Hamill, "From Special Privilege," n. 220, p. 138. "Public corporations, including municipalities, public utilities, nonprofit organizations, and educational institutions which never posed a serious question concerning the primary regulatory power resting with the states."
} 
act limits on capitalization. ${ }^{82}$ In total, 17,648 of 19,998 special charters were special because of well-understood difficulties in implementing general laws for these types of corporations.

Of the remaining 2,350 special charters, issued to companies in a wide variety of industries. "Only 153, or seven percent, of the almost 2,200 special charters issued to private business corporations contained evidence of providing benefits not available under the applicable general law." In other words, there was nothing special about these special incorporations. "By far the greatest number of these [153] special charters, seventy-nine, were issued to relax the capital limitations imposed by the applicable general law." 83 Another 40 charters were special because of technicalities in stock issues or company duration. In short, of the 19,998 corporations receiving special charters, at most 34 charters really conferred special privileges, such as tax exemptions, not available to all corporations. The shift to mandatory general incorporation was equally successful at increasing the number of corporations in the United States and limiting the number of corporations with truly special privileges. $^{84}$

\section{CONCLUSIONS}

The Constitution and Bill of Rights of the United States provided an invaluable framework supporting American economic development in the nineteenth century. Textual change in the national constitution, however, is glacial, and substantive change occurs through judicial reinterpretation. ${ }^{85}$ It would be a mistake, however, to assume that only the experience of the national government and the national constitution can teach us relevant lessons about economic development. Most of the fea-

\footnotetext{
${ }^{82}$ Hamill, "From Special Privilege" n. 222, p. 138. My interpretation of special charters in transportation, communications, banking, and finance differs somewhat from Hamill's. She places great importance on the regulatory function of special charters.

${ }^{83}$ Both quotes from Hamill, "From Special Privilege" p. 161. In note 298, p. 160, Hamill gives the count of private businesses receiving special charters at 2,350, but in the text she gives the figure of "almost 2,200 " special charters. I cannot determine why the two totals are different.

${ }^{84}$ Hamill's compilation of the 19,998 charters is an enormous accomplishment deserving of great praise. Hamill's conclusions regarding the use of special charters to regulate business activity and the timing of special charters issues, as well as her overall history of charter policy from the early nineteenth century onwards poses some problems. There is not space to go into my concerns here, but anyone using Hamill's conclusions as a starting point for their research, should not accept these assertions at face value but delve more deeply into the history.

${ }^{85}$ Thus Persson and Tabellini, Constitutuions, pp. 83-100, for example, measure constitutional provisions in the United States as fixed since 1800 because they focus only on the national government. Neither suffrage, electoral rules, or the internal balance of executive and legislative power stayed constant in the states since 1800 .
} 
tures of modern economic institutions associated with successful economic development-legal origins and legal systems, the form of corporate organization and governance, and the presence of hard budget constraints - were areas of American institutional development controlled by the state, not national, governments. States continuously revise and change their constitutions, and many of the changes are conscious efforts to shape economic institutions.

In the early nineteenth century the adoption of widespread suffrage and democratic forms of government gave voice to a popular mandate for government promotion of transportation and finance. States actively intervened in the economy to promote banks, canals, and later railroads. Their development schemes ranged from the conservative and prudential to the wildly naive and improvident. There were problems with venal corruption, but the primary concern of the constitutional conventions that met in the 1840 s and 1850 s was not that human beings were corruptible. Instead, they saw that the very nature of the democratic process made certain ways of doing things, taxless finance in particular, appear very attractive ex ante to policy makers.

States, in general, did not respond to the fiscal crisis of the early 1840 s by prohibiting government borrowing, banning investment in canals, permanently revoking bank charters, or instituting new and stricter penalties for officials who abused their offices (although a few did). States wanted to provide financial and transportation infrastructure. They believed, strongly and actively, that the impartial and effective provision of these services was exactly the kind of thing that a good government should do. But they did not want infrastructure investment or corporate chartering to distort how the political system worked. So they changed the rules. Their solutions were indirect. Rather than making it illegal for legislators to profit from the sale of special corporate charters, they required strict free access to the corporate form, guaranteeing free entry into most lines of business and reducing the rents available to politicians from manipulating chartering. Rather than banning public provision of canals, railroads, or banks, they required that voters approve tax increases for the projects before any money was borrowed. This did not eliminate naive and foolish projects, but it significantly raised the ex ante cost of getting proposals implemented. Equally important, it did not eliminate the possibility of pursuing good projects. 
Constitutions, Corporations, and Corruption

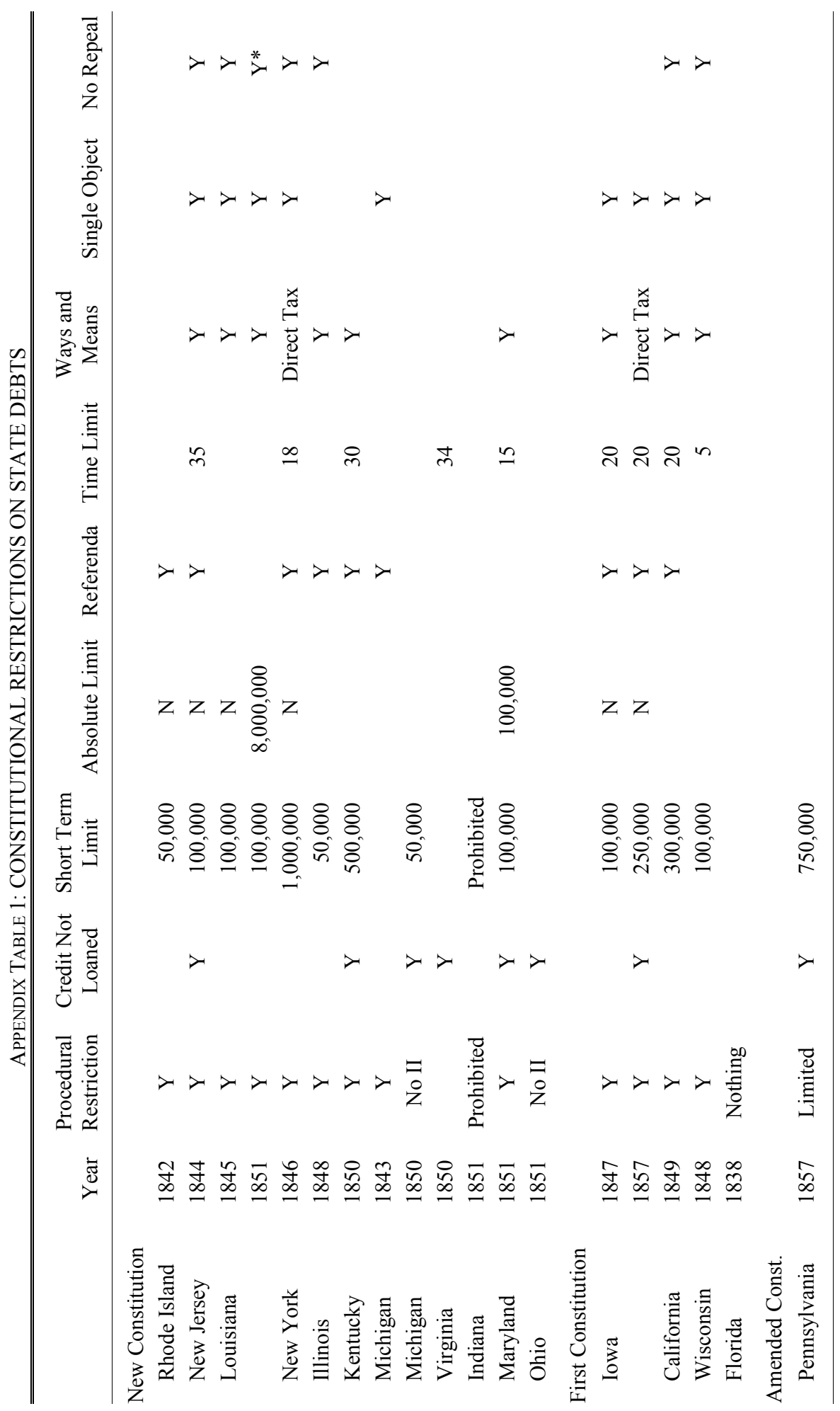


APPENDIX TABLE 1 - continued

Notes: Constitutional provisions were taken from the text of the relevant constitutions. The texts are available online at Wallis, NBER/Maryland Constitution Project, or from Thorpe, Constitutions.

Procedural Restriction is "Y" if state has some legislature cannot increase debt unilaterally, and is "No II" if state cannot issue debt for internal improvements. Credit Not Loaned is "Y" if state cannot loan credit to private individual or corporation. Short Term Limit is the dollar limit on "casual debt" Absolute Limit is limit of the total amount of debt outstanding, regardless of purpose. Referenda is "Y" if voter approval is required for debt issue (aside from casual debt). Time Limit is the maximum number of years bonds can be issued for. Ways and Means is "Y" if a taxes must be provided to service the debt. Direct Tax is "Y" if a property tax increase must be provided. Single Object is "Y" if legislation authorizing debt must be constrained to one object. No Repeal is "Y" if the laws authorizing taxation cannot be repealed, are "irrepealable." The Louisiana constitution of 1851 required that taxes be irrepealable "unless the repealing law contains some other adequate provision for the payment of the principal and interest of the debt" Section 111, Article 6 .

APPENDIX TABLE 2

Notes: The Louisiana constitution in 1851 allowed investment in Internal Improvement Companies up to $1 / 5$ of their capital. Investment Prohibited: State (Local) government prohibited from investing in corporations. General Laws: Corporations can be created under General Incorporation Acts. Special Prohibited: State cannot, under usual circumstances, create corporations by Special Act. Special Absolute: State can never create corporations by Special Act. Repeal or Revoke is "Y" if general laws may be repealed or altered.

Banks: No - Banks Prohibited. General - Banks allowed under General Act only, General/Voters - Banks allowed only if voters approve a General Incorporation Act. Deposit - In California the only banks allowed are deposit banks, no money creating banks. 6 months - In Pennsylvania, bank charters had a six-month waiting period. 
Constitutions, Corporations, and Corruption

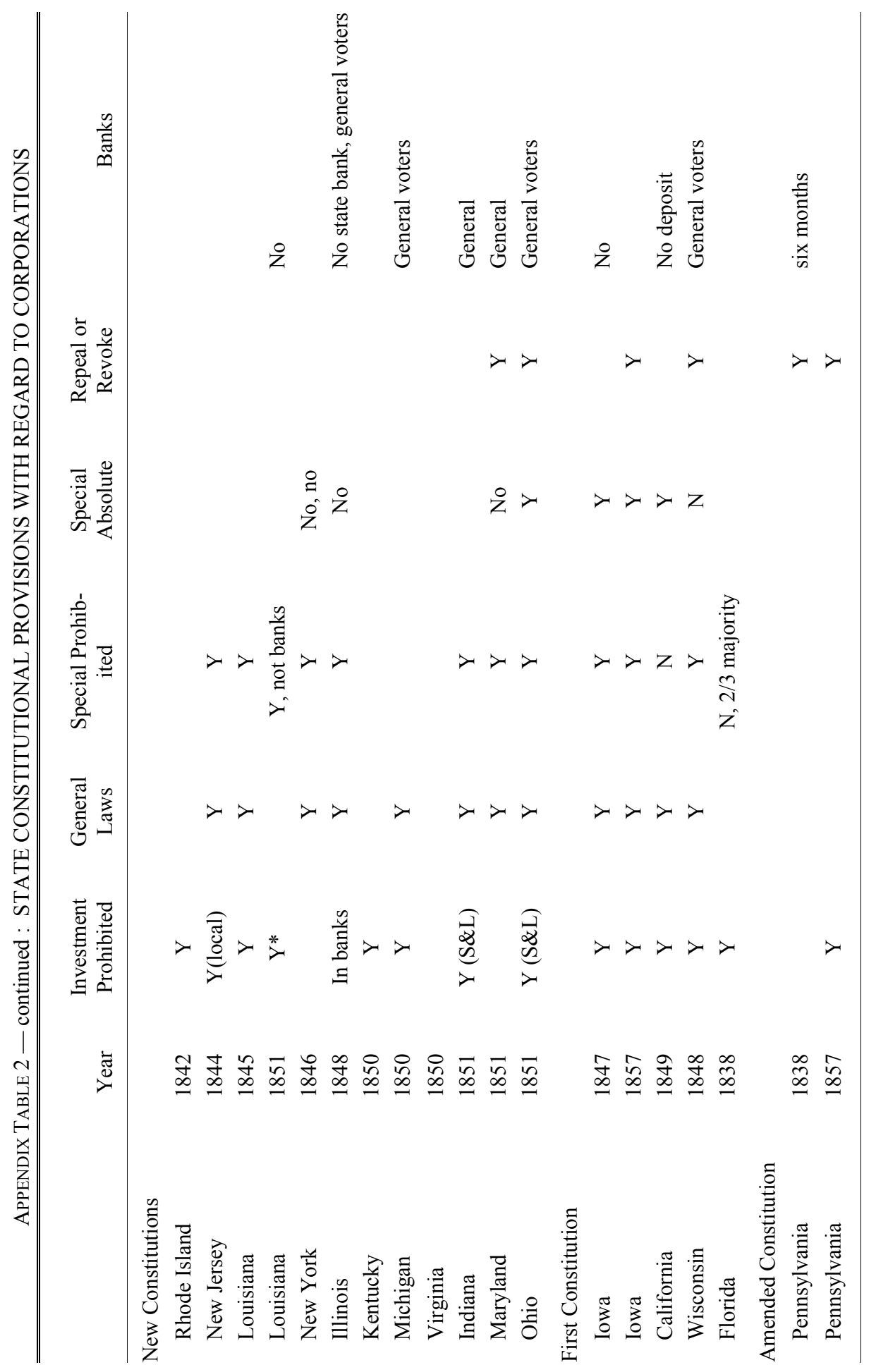


APPENDIX TABLE 3 STATE CONSTITUTIONAL PROVISIONS WITH REGARD TO TAXATION

\begin{tabular}{|c|c|c|c|c|c|}
\hline & & & Uniform Rules & Taxed by Value & Equal Rate \\
\hline \multicolumn{6}{|c|}{ Wrote New Constitutions } \\
\hline Rhode Island & 1842 & & & & \\
\hline New Jersey & 1844 & & $\mathrm{Y}$ & $\mathrm{Y}$ & \\
\hline Louisiana & 1845 & & $\mathrm{Y}$ & $\mathrm{Y}$ & \\
\hline Louisiana & 1851 & & $\mathrm{Y}$ & $\mathrm{Y}$ & \\
\hline New York* & 1846 & nothing & & & \\
\hline Illinois & 1848 & & Y (local) & $\mathrm{Y}$ & \\
\hline Kentucky & 1850 & nothing & & & \\
\hline Michigan* & 1850 & & Y & $\mathrm{Y}$ & $\mathrm{Y}$ \\
\hline Virginia & 1850 & & $\mathrm{Y}$ & $\mathrm{Y}$ & $\mathrm{Y}$ \\
\hline Indiana & 1851 & & $\mathrm{Y}$ & $\mathrm{Y}$ & $\mathrm{Y}$ \\
\hline Maryland & 1851 & & & $\mathrm{Y}$ & \\
\hline Ohio & 1851 & & $\mathrm{Y}$ & & \\
\hline \multicolumn{6}{|c|}{ Wrote First Constitution } \\
\hline Iowa & 1847 & nothing & & & \\
\hline Iowa & 1857 & nothing & & & \\
\hline California & 1849 & & $\mathrm{Y}$ & $\mathrm{Y}$ & $\mathrm{Y}$ \\
\hline Wisconsin & 1848 & & $\mathrm{Y}$ & & \\
\hline Florida & 1838 & & $\mathrm{Y}$ & & $\mathrm{Y}$ \\
\hline \multicolumn{6}{|l|}{ Other States } \\
\hline Tennessee & 1834 & & $\mathrm{Y}$ & $\mathrm{Y}$ & \\
\hline Maine* & 1819 & & & $\mathrm{Y}$ & $\mathrm{Y}$ \\
\hline
\end{tabular}

Notes: Uniform Rules in "Y" if all property is to be taxed under uniform rules. Taxed by Value is " $\mathrm{Y}$ " if all property is to be assessed at market values; and Equal Rates is "Y" if all property is to be taxed at the same rate.

\section{REFERENCES}

Acemoglu, Daron, Simon Johnson, and James A. Robinson. "The Colonial Origins of Comparative Development: An Empirical Investigation." American Economic Review 91 (December 2001): 1369-1401.

. "Reversal of Fortune: Geography and Institutions in the Making of the Modern World Income Distribution," Quarterly Journal of Economics 117 (November 2002): 1231-94.

Adams, Willi Paul. The First American Constitutions. Expanded Edition, Lanham, MD: Rowman and Littlefield, 2001.

Angell, Joseph K., and Samuel Ames. A Treatise of the Law of Private Corporations Aggregate. 1832. (Reprint, New York: Arno Press, 1972).

Bailyn, Bernard. The Ideological Origins of the American Revolution. Cambridge, MA: Harvard University Press, 1967.

Beck, Thorsten, and Ross Levine, "Legal Institutions and Financial Development." NBER Working Paper 10126, December 2003.

Benson, George C., Sumner Benson, Harold McClelland, and Procter Thomson. The American Property Tax: Its History, Administration, and Economic Impact. Claremont, CA: College Press, 1965.

Benson, Lee. The Concept of Jacksonian Democracy: New York as a Test Case. Princeton, NJ: Princeton University Press, 1961.

Bodenhorn, Howard. A History of Banking in Antebellum America. Cambridge: Cam- 
bridge University Press, 2000.

. State Banking in Early America: A New Economic History. Oxford: Oxford University Press, 2003.

. "Bank Chartering and Political Corruption in Ante-Bellum New York: Free Banking as Reform.” NBER Working Paper, W 10479, May 2004.

Brantley, William H. Banking in Alabama, 1816-1860. Privately Printed, 1961.

Cadman, John W. The Corporation in New Jersey: Business and Politics, 1791-1875. Cambridge, MA: Harvard University Press, 1949.

Caldwell, S. A. A Banking History of Louisiana. Baton Rouge: Louisiana State University Press, 1937.

Callender, Guy Stevens. "The Early Transportation and Banking Enterprises of the States." Quarterly Journal of Economics 17, no. 1 (November, 1902): 111-62.

Carmony, Donald. F. Indiana 1816-1850: The Pioneer Era. Indianapolis: Indiana Historical Bureau and Indiana Historical Society, 1998.

Davis, John P. Corporations: A Study of the Development of the Origin and Development of Great Business Combinations and their Relation to the Authority of the State. New York: Capricorn, 1961.

Dodd, Edwin Merrick. American Business Corporations until 1860; with Special Reference to Massachusetts. Cambridge, MA: Harvard University Press, 1954.

Dodd, Edwin Merrick. "Statutory Developments in Business Corporation Law, 18861936." Harvard Law Review 50 (1936): 27.

Dunlavy, Colleen A. "From Citizens to Plutocrats: Nineteenth Century Shareholder Voting Rights and Theories of the Corporation." In Crossing Corporate Boundaries: History, Politics, and Culture, edited by Kenneth Lipartito and David B. Sicilia, 66-93. New York: Oxford University Press, 2004.

Einhorn, Robin. "Species of Property: The American Property Tax Uniformity Clauses Reconsidered." This JOURNAL 61, no. 4 (2001): 973-1007.

Esarey, Logan. A History of Indiana: From its Exploration to 1860. Indianapolis: B. F. Bowen and Company, 1918.

Evans, George Heberton. Business Incorporations in the United States, 1800-1943. NBER, Baltimore: Waverly Press, 1948.

Ford, Thomas. A History of Illinois form its Commencement as a State in 1818 to 1847. Vol. 2 Chicago: The Lakeside Press, 1946.

Goodrich, Carter. "The Virginia System of Mixed Enterprise: a Study of State Planning of Internal Improvement." Political Science Quarterly 64 (1949): 355-87.

. "The Revulsion Against Internal Improvements." This Journal 10, no. 2 (1950): 145-69.

. Government Promotion of American Canals and Railroads. New York: Columbia University Press, 1960.

Gunn, L. Ray. The Decline of Authority: Public Economic Policy and Political Development in New York, 1800-1860. Ithaca, NY: Cornell University Press, 1988.

Haig, Robert Murray. History of the Property Tax in Illinois, Illinois Studies in the Social Sciences. Urbana: The University of Illinois, 1914.

Hamill, Susan Pace. "From Special Privilege to General Utility: A Continuation of Willard Hurst's Study of Corporations." American University Law Review 49, no. 1 (1999): 81-180.

Handlin, Oscar, and Mart Flug Handlin. Commonwealth: A Study of the Role of Government in the American Economy: Massachusetts, 1774-1861. Cambridge: Belknap Press, 1969.

Hartz, Louis. 1948. Economic Policy and Democratic Thought: Pennsylvania, 1776- 
1860. Chicago: Quadrangle Books, 1948.

Heath, Milton. Constructive Liberalism: The Role of the State in Economic Development in Georgia to 1860. Cambridge, MA: Harvard University Press, 1954.

Hofstadter, Richard. The Idea of a Party System. Berkeley: University of California Press, 1969.

Holt, Michael F. The Political Crisis of the 1850s. New York: Norton, 1978.

. The Rise and Fall of the American Whig Party. New York: Oxford University Press, 1999.

Hurst, James Willard. The Legitimacy of the Business Corporation in the Law of the United States, 1780-1970. Charlottesville: University of Virginia Press, 1970.

Indiana Debates, Report of the Debates and Proceedings of the Convention for the Revision of the Constitution, The State of Indiana. Indianapolis, IN: H. Fowler, 1850.

Inman, Robert P. "Transfers and Bailouts: Enforcing Local Fiscal Discipline with Lessons from U.S. Federalism." In Fiscal Decentralization and the Challenge of Hard Budget Constraints edited by Jonathan Rodden and Gunnar S. Eskeland, 35-84. Boston: MIT Press, 2003.

Kessler, William C. "Incorporation in New England: A Statistical Study, 1800-1875." This JOURNAL 8, no. 1 (1948): 43-62.

Kruman, Marc W. Between Authority and Liberty: State Constitution Making in Revolutionary America. Chapel Hill: University of North Carolina Press, 1997.

Lamoreaux, Naomi. "Partnerships, Corporations, and the Limits on Contractual Freedom in U.S. History: An Essay in Economics, Law, and Culture." In Crossing Corporate Boundaries: History, Politics, and Culture, edited by Kenneth Lipartito and David B. Sicilia, 29-65. New York: Oxford University Press, 2004.

Lamoreaux, Naomi, and Jean-Laurent Rosenthal. "Legal Regime and Business's Organizational Choice.” NBER Working paper 10288, February, 2004.

Larson, John Lauritz. Internal Improvement: National Public Works and the Promise of Popular Government in the Early United States. Chapel Hill: University of North Carolina Press, 2001.

Leggett, William. Democratick Editorials: Essays in Jacksonian Political Economy. Indianapolis, IN: Liberty Press, 1984.

Maier, Pauline, "The Debate Over Incorporations: Massachusetts in the Early Republic." In Massachusetts in the New Nation, edited by Conrad Wright, 73-117. Boston: Massachusetts Historical Society, 1992.

. "The Revolutionary Origins of the American Corporation." William and Mary Quarterly, 3d series, 50, 1 (January 1993): 51-84.

Malone, Laurence J. Opening the West: Federal Internal Improvements Before 1860. Westport, CT: Greenwood Press, 1998.

Matthews, Richard K. ed. Virtue, Corruption, and Self-Interest. Bethlehem, PA: Lehigh University Press, 1994.

McGrane, Reginald C. Foreign Bondholders and American State Debts. New York: Macmillan Company, 1935.

Miller, Nathan. The Enterprise of A Free People: Aspects of Economic Development in New York State during the Canal Period, 1792-1838. Ithaca, NY: Cornell University Press, 1962.

Mitchell, William E. "The Effectiveness of Debt Limits on State and Local Government Borrowing." The Bulletin, 45 (October 1967) New York University, Graduate School of Business Administration.

Murrin, John M. "Escaping Perfidious Albion: Federalism, Fear of Corruption, and 
Democratization of Corruption in Postrevolutionary America." In Virtue, Corruption, and Self-Interest, edited by Richard K. Matthews, 103-47. Bethlehem, PA: Lehigh University Press, 1994.

Niou, Emerson M. S., and Peter C. Ordeshook. "Universalism in Congress." American Jounal of Political Science 298, (May, 1985): 246-90.

Pocok, J. G. A. Virtue, Commerce, and History. Cambridge: Cambridge University Press, 1985.

Qian, Yingyi, and Barry R. Weingast. "Federalism as a Commitment to Preserving Market Incentives." Journal of Economic Perspectives 11, 4 (Autumn, 1997): 83-92.

Ratchford, B. U. American State Debts. Durham, NC: Duke University Press, 1941.

Richardson, James D. The Messages and Papers of the Presidents. Washington, DC: Bureau of National Literature, 1897.

Rockoff, Hugh. "The Free Banking Era: A Reexamination." Journal of Money, Credit and Banking 6, no. 2 (May 1974): 141-67.

Rodden, Jonathan, and Gunnar S. Eskeland, eds. Fiscal Decentralization and the Challenge of Hard Budget Constraints. Boston: MIT Press, 2003.

Rodrick, Dani, Arvind Subramanian, and Francesco Trebbi. "Institutions Rule: The Primacy of Institutions over Geography and Integreation in Economic Development." NBER Working Paper, 9305, October 2002.

Scheiber, Harry N. Ohio Canal Era: A Case Study of Government and the Economy, 1820-1861. Athens: The Ohio State University Press, 1969.

Schwartz, Anna. "The Beginning of Competitive Banking in Philadelphia." In Money in Historical Perspective. NBER, Chicago: University of Chicago Press, 1987.

Schweikart, Larry. Banking in the American South from the Age of Jackson to Reconstruction. Baton Rouge: Louisiana State University Press, 1987.

Seavoy, Ronald E. The Origins of the American Business Corporation, 1784-1855. Westport, CT: Greenwood Press, 1982.

Shepsle, Kenneth A., and Barry R. Weingast. "Political Solutions to Market Problems." American Political Science Review 78 (June, 1984): 417-34.

Shalhope, Robert E. "Toward a Republican Synthesis: The Emergence of an Understanding of Republicanism in American Historiography." The William and Mary Quarterly, 3rd Ser., 29, no. 1. (January 1972): 49-80.

. "Republicanism and Early American Historiography." The William and Mary Quarterly, 3rd Ser., 39, no. 2. (April 1982): 334-56.

Shleifer, Andrei, and Rovert W. Vishny. "Corruption." Quarterly Journal of Economics 108, no. 3, (1993): 599-617.

Sparks, Earl Sylvester. History and Theory of Agricultural Credit in the United States. New York: Thomas Crowell, 1932.

Sylla, Richard, John B. Legler, and John Joseph Wallis. "Banks and State Public Finance in the New Republic." This Journal 47, no. 2 (1987): 391-403.

Tarr, Alan Understanding State Constitutions. Princeton, NJ: Princeton University Press, 1998.

Thorpe, Francis Newton, The Federal and State Constitutions, Colonial Charters, and the Organic Laws of the State, Territories, and Colonies; Now or heretofore Forming the United States of America. Washington, DC: GPO, 1909.

Troesken, Werner. "The Institutional Antecedents of State Utility Regulation: The Chicago Gas Industry, 1860 to 1913." In The Regulated Economy: A Historical Approach to Political Economy, edited by Claudia Goldin and Gary D. Libecap, 55-80. Chicago: University of Chicago Press, 1994. 
United States Census. Report on Valuation, Taxation and Public Indebtedness in the United States. Washington, DC: GPO, 1884.

Wallenstein, Peter. From Slave South to New South: Public Policy in Nineteenth Century Georgia. Chapel Hill: University of North Carolina Press, 1987.

Wallis, John Joseph. "American Government Finance in the Long Run: 1790 to 1990." Journal of Economic Perspectives 14, no. 1, (January, 2000): 61-82 .

. "History of the Property Tax." In Property Taxation and Local Government Finance, edited by Wallace E. Oates, 123-47. Cambridge: Lincoln Institute, 2001: 123, 147.

. "Market Augmenting Government? The State and the Corporation in 19th Century America." In Market-Augmenting Government: The Institutional Foundations for Prosperity, edited by Omar Azfar and Charles Cadwell, 223-65. Ann Arbor: University of Michigan Press, 2003.

. "The Property Tax as a Coordination Device: Financing Indiana's Mammoth System of Internal Improvements." Explorations in Economic History 40, no. 3 (July 2003): 223-50.

. "The Concept of Systematic Corruption in American Political and Economic History." In Corruption and Reform, edited by Claudia Goldin and Ed Glaeser. forthcoming, 2005.

.The NBER/Maryland State Constitution Project, http://129.2.168.174/ constitution/.

Wallis, John Joseph, Richard Sylla, and Arthur Grinath III "Sovereign Debt and Repudiation: The Emerging-Market Debt Crisis in U.S. States, 1839-1843." NBER Working Paper, 2004.

Wallis, John Joseph, Richard Sylla and John Legler. "The Interaction of Taxation and Regulation in Nineteenth Century Banking." In The Regulated Economy: A Historical Approach to Political Economy, edited by Claudia Goldin and Gary Libecap, 121-44. Chicago: University of Chicago Press, 1994.

Weingast, Barry R. "A Rational Choice Perspective on Congressional Norms." American Journal of Political Science 23, no. 2 (1979): 245-62.

Weingast, Barry R., Kenneth A. Shepsle, and Christopher Johnsen. "The Political Economy of Benefits and Costs: A Neoclassical Approach to Distributive Politics." Journal of Political Economy 89, no. 4 (August, 1981): 642-64.

Worley, Ted R. "The Control of the Real Estate Bank of the State of Arkansas, 18361855." The Mississippi Valley Historical Review 37, no. 3 (December 1950): 403-26.

. "Arkansas and the Money Crisis of 1836-1837." The Journal of Southern History 15, no. 2 (May 1949): 178-91. 